\title{
Vulnerability assessment of archaeological sites to earthquake hazard: an indicator based method integrating spatial and temporal aspects
}

\author{
Despina Minos-Minopoulos ${ }^{1}$, Dale Dominey-Howes ${ }^{2,},{ }^{*}$ Kosmas Pavlopoulos ${ }^{3}$ \\ ${ }^{1}$ Ministry of Culture and Sports, Ephorate of Paleoanthropology-Speleology, Athens, Greece \\ 2 The University of Sydney, School of Geosciences, Sydney, Australia \\ 3 Paris Sorbonne University Abu Dhabi, Abu Dhabi, UAE
}

\section{Article history}

Received September 15, 2016; accepted June 6, 2017.

Subject classification:

Vulnerability assessment, Earthquakes, Archaeological sites.

\begin{abstract}
Across the world, numerous sites of cultural heritage value are at risk from a variety of human-induced and natural hazards such as war and earthquakes. Here we present and test a novel indicator-based method for assessing the vulnerability of archaeological sites to earthquakes. Vulnerability is approached as a dynamic element assessed through a combination of spatial and temporal parameters. The spatial parameters examine the susceptibility of the sites to the secondary Earthquake Environmental Effects of ground liquefaction, landslides and tsunami and are expressed through the Spatial Susceptibility Index (SSi). Parameters of physical vulnerability, economic importance and visitors density examine the temporal vulnerability of the sites expressed through the Temporal Vulnerability Index (TVi). The equally weighted sum of the spatial and temporal indexes represents the total Archaeological Site Vulnerability Index (A.S.V.I.). The A.S.V.I method is applied at 16 archaeological sites across Greece, allowing an assessment of their vulnerability. This then allows the establishment of a regional and national priority list for considering future risk mitigation. Results indicate that i) the majority of the sites have low to moderate vulnerability to earthquake hazard, ii) Neratzia Fortress on Kos and Heraion on Samos are characterised as highly vulnerable and should be prioritised for further studies and mitigation measures, and iii) the majority of the sites are susceptible to at least one Earthquake Environmental Effect and present relatively high physical vulnerability attributed to the existing limited conservation works. This approach highlights the necessity for an effective vulnerability assessment methodology within the existing framework of disaster risk management for cultural heritage.
\end{abstract}

\section{Introduction}

The vulnerability of cultural heritage sites is described as the susceptibility or exposure of heritage property to hazards [UNESCO 2010]. The description expresses the inherent weakness of a heritage property due to its location (and therefore its exposure) to primary or secondary hazard events and processes, and to its physical, social, economic and institutional characteristics [Jigyasu 2005]. These characteristics vary widely since each heritage property is unique due to its age, structural and architectural characteristics and the mechanisms by which it may be damaged. The parameterization of economic, cultural, religious and artistic properties is considered controversial and difficult to assess [Delmonaco and Margottini 2009]. Consequently, each property is commonly examined as a case study and assessments focus primarily on the physical vulnerability of the site with limited attention that incorporates heritage values [Carlon et al. 2002] or historical, cultural, economical and social impacts [Delmonaco and Margottini 2009].

Assessments of the physical vulnerability of cultural heritage sites to earthquake hazard has mainly been undertaken through the applied sciences. For example, using seismic input data, the structural fragility of historical monuments has been calculated as part of seismic risk assessments. Local site effects due to geological or geomorphological properties of the substratum are incorporated as seismic input parameters expressed and examined through variations in peak ground acceleration [Di Capua et al. 2006, Lagomarsino 2006, Lagomarsino and Cattari 2015].

Earth sciences on the other hand has focused mainly on the exposure of cultural heritage to threats posed by hydrogeological hazards. Studies of slope instability, soil erosion, fluvial and coastal processes [Canuti et al. 2000, Nikolova et al. 2012, Reeder et al. 
2012, Reeder-Myers 2015] suggest that the intrinsic conditions of an archaeological site that make it vulnerable to experiencing the negative effects of ground instabilities represent important spatial parameters that contribute to the vulnerability of archaeological sites to natural hazards. Through a review of cultural heritage and landslides, Canuti et al. [2009] stressed the importance of engineering geology to the protection of cultural heritage from natural hazards via geotechnical assessment of risk. This allows effective conservation measures to be developed that can contribute to the reduction of the vulnerability of cultural heritage.

With regard to ground instabilities and deformation triggered by earthquakes - known as Earthquake Environmental Effects (EEEs) - these represent co-seismic geological effects either directly linked to the earthquake source (e.g., surface faulting, regional uplift and subsidence) or are associated with ground shaking (e.g., tsunamis, liquefaction ground resonance, landslides and ground failures) and are controlled and induced by the local geological setting [Serva et al. 2015, Michetti et al. 2015]. Therefore, the location and foundation ground of an archaeological site represent crucial vulnerability parameters since their susceptibility to deformation during a seismic event relates to direct effects on the monuments and cultural landscape of the site.

Taking into consideration the idea that vulnerability is a dynamic element incorporating temporal and spatial aspects [Papathoma-Köhle et al. 2007, Calgaro et al. 2014], this study aims to develop, apply and examine a method for assessing the vulnerability of archaeological sites to earthquake hazard [Minos-Minopoulos 2015]. Following an earth sciences approach, the vulnerability of 16 archaeological sites in Greece are examined and assessed through an indicator-based method that integrates spatial and temporal parameters. The method allows the identification of the root causes of vulnerability to earthquake hazard for each site. Additionally, through the Archaeological Site Vulnerability Index (A.S.V.I) assessment, it is possible to prioritize sites regionally and nationally for further study and appropriate vulnerability reduction measures.

\section{Methods}

The conceptual framework highlights that the vulnerability of an archaeological site is not only limited to the physical vulnerability of its monuments which is commonly assessed through vulnerability curves expressing potential seismic waves impact on the structures. The assessment follows the general framework of the earth sciences principles with emphasis on the spatial aspects of vulnerability expressed through the susceptibility of archaeological sites to the secondary Earthquake Environmental Effects (EEEs) of ground liquefaction, landslides and tsunami, as defined by Michetti et al. [2007] through the ESI-07 intensity scale. The susceptibility of a site to EEEs directly relates to potential damage the monuments will suffer due to ground deformation processes, a parameter not incorporated in the majority of the applied sciences vulnerability assessment studies [Bird and Bommer 2004]. The temporal aspects of vulnerability are examined through physical, economic and social parameters that vary through time in order to promote the dynamic nature of vulnerability.

\subsection{Sites under study}

The archaeological sites selected for analysis are located in Greece, in the tectonically active regions of Corinth, Samos, Kos and Santorini (Figure 1; Table 1). They were selected in order to capture a variety of geotectonic regimes reflecting the complex geodynamic setting of Greece. They also represent variations in:

- Thematic categories of use - ranging from administrative centres, agoras, harbours, defensive structures, sanctuaries and temples.

- Periods of use - ranging from prehistory and antiquity to Byzantine and Post-Byzantine periods

- Geomorphological setting - ranging from coastal zone, continental to semi-mountainous settings.

- Land use - with sites located in the built environment (urban centres and settlements) and sites located in semi-natural habitats.

- Designation status - with the archaeological sites of Samos being designated by UNESCO as World Heritage Sites while the rest of the sites are designated as national scheduled monuments.

Archaeological sites in Corinth were selected as the pilot study for the application of the new method since the region includes an extensive record of historical and modern seismicity and because a considerable literature in the field of geosciences as well as a detailed archaeological archive of systematic excavations is available from the American School of Classical Studies in Athens. The method was then used in Samos, Kos and Santorini in order to test and expand its applicability, identify potential inconsistencies or contradictions and perform any necessary refinements. 


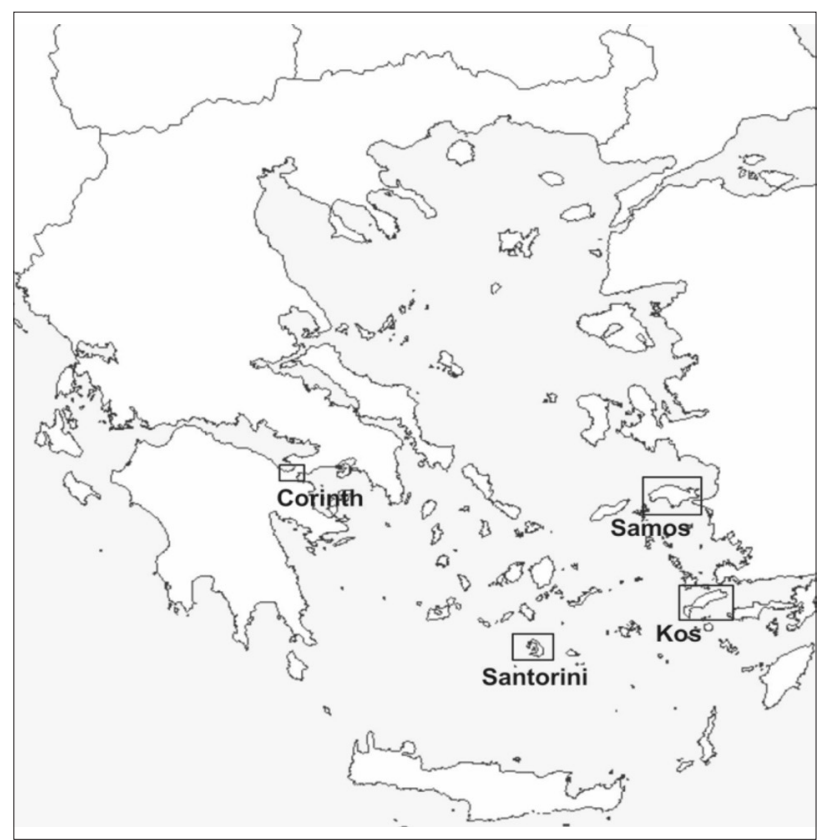

Figure 1. Map of Greece with the regional locations of the archaeological sites under study.

\subsection{Indicator based method}

The sites were examined mainly in terms of their intrinsic geological and geomorphological properties, their physical vulnerability and their use. These were expressed through sets of indicators for spatial susceptibility and temporal vulnerability (Tables 2-5).

The spatial parameters in this study focus on the susceptibility of the archaeological sites to the secondary Earthquake Environmental Effects, (EEEs) of ground liquefaction, landslides and tsunamis, induced by ground shaking and that are controlled by the local geological setting because international research by leading experts including Serva et al. [2015] and Michetti et al. [2015] imply these are the most significant controls.

Assessment of the susceptibility of each site is based on a set of geological and geomorphological factors associated with each EEE derived from a review of the extensive literature cited in Table 2. A number of parameters including (i) historical records, relative studies in the field of each environmental effect, (ii) Earthquake Archaeological Effects (EAEs) related to ground deformation [Rodríguez-Pascua et al. 2011] and (iii) interventions either performed during antiquity or during modern times indicative of active geological and geomorphological processes, are also included in the assessment for each EEE through the Archaeological Site Factor.

Each factor is assigned a weight according to its relative importance to the aims of this study. The weighting takes account of expert qualitative judgments derived from an analysis of the literature (Table 2). Each factor's classes are standardized with linear scaled values from 0 to 1 following the Analytic Hi-

\begin{tabular}{|c|c|c|c|c|c|}
\hline $\begin{array}{l}\text { Archaeological } \\
\text { Sites }\end{array}$ & Depositional Environment & Water Table & Age & Site Factor & $L q S i$ \\
\hline \multicolumn{6}{|l|}{ Corinth } \\
\hline Agora & 0 & 0 & 0.08 & 0 & 0.08 \\
\hline Theatre & 0.4 & 0 & 0.2 & 0.06 & 0.66 \\
\hline Odeion & 0 & 0 & 0.08 & 0 & 0.08 \\
\hline Lechaion & 0.4 & 0.3 & 0.2 & 0.1 & 1 \\
\hline Kenchreai & 0.4 & 0.3 & 0.2 & 0.06 & 0.96 \\
\hline \multicolumn{6}{|l|}{ Kos } \\
\hline Neratzia Fortress & 0.24 & 0.3 & 0.2 & 0 & 0.74 \\
\hline Ancient Agora & 0.24 & 0.255 & 0.2 & 0 & 0.695 \\
\hline West Arch. Site & 0.24 & 0.18 & 0.2 & 0.06 & 0.68 \\
\hline Altar of Dionysus & 0.24 & 0.18 & 0.2 & 0 & 0.62 \\
\hline Asklepieion & 0 & 0 & 0 & 0.03 & 0.03 \\
\hline \multicolumn{6}{|l|}{ Samos } \\
\hline Heraion & 0.24 & 0.3 & 0.2 & 0.06 & 0.80 \\
\hline Roman Baths & 0.4 & 0.3 & 0.2 & 0 & 0.9 \\
\hline Eupalinos Tunnel & 0 & 0 & 0 & 0 & $\mathbf{0}$ \\
\hline Logothetis Castle & 0 & 0.09 & 0 & 0 & 0.09 \\
\hline \multicolumn{6}{|l|}{ Santorini } \\
\hline Akrotiri & 0 & 0 & 0.2 & 0.06 & 0.26 \\
\hline Ancient Thera & 0 & 0 & 0 & 0 & $\mathbf{0}$ \\
\hline
\end{tabular}

Table 1. Liquefaction Susceptibility indicator weighted factors and scores for the archaeological sites under study. 


\begin{tabular}{|c|c|c|c|c|c|c|}
\hline \multirow{2}{*}{$\begin{array}{l}\text { Archaeological } \\
\text { Sites }\end{array}$} & \multicolumn{5}{|c|}{$L s S i$} & \multirow{2}{*}{ Score } \\
\hline & S.A. & S.F. & E. & L. & T.L.P. & \\
\hline \multicolumn{7}{|l|}{ Corinth } \\
\hline Agora & 0.3 & 0.3 & 0 & 0.075 & 0 & 0.675 \\
\hline Theatre & 0.3 & 0.18 & 0 & 0.075 & 0 & 0.55 \\
\hline Odeion & 0.06 & 0 & 0 & 0.075 & 0 & 0.135 \\
\hline Lechaion & 0.06 & 0.09 & 0.2 & 0.075 & 0.05 & 0.425 \\
\hline Kenchreai & 0.06 & 0 & 0.2 & 0.075 & 0 & 0.335 \\
\hline \multicolumn{7}{|l|}{ Kos } \\
\hline Neratzia Fortress & 0 & 0 & 0.16 & 0.075 & 0 & 0.235 \\
\hline Ancient Agora & 0 & 0 & 0.1 & 0.075 & 0 & 0.175 \\
\hline West Arch. Site & 0.06 & 0 & 0.04 & 0.075 & 0 & 0.175 \\
\hline Altar of Dionysus & 0 & 0 & 0.04 & 0.075 & 0 & 0.115 \\
\hline Asklepieion & 0.21 & 0.18 & 0.16 & 0.09 & 0.1 & 0.74 \\
\hline \multicolumn{7}{|l|}{ Samos } \\
\hline Heraion & 0 & 0 & 0.2 & 0.075 & 0 & 0.275 \\
\hline Roman Baths & 0 & 0 & 0.1 & 0.075 & 0 & 0.175 \\
\hline Eupalinos Tunnel & 0.3 & 0.3 & 0.04 & 0.09 & 0 & 0.73 \\
\hline Logothetis Castle & 0.3 & 0.3 & 0.2 & 0.09 & 0 & 0.89 \\
\hline \multicolumn{7}{|l|}{ Santorini } \\
\hline Akrotiri & 0.21 & 0.18 & 0.04 & 0.075 & 0 & 0.505 \\
\hline Ancient Thera & 0.3 & 0.3 & 0.04 & 0.02 & 0.1 & 0.76 \\
\hline
\end{tabular}

Table 2. Landslide Susceptibility indicator weighted factors and scores for the archaeological sites under study.

\begin{tabular}{|c|c|c|c|c|}
\hline \multirow[b]{2}{*}{ Archaeological Sites } & \multicolumn{3}{|c|}{ Tsunami Susceptibility Indicator } & \multirow[b]{2}{*}{ Score } \\
\hline & Inundation Depth & $\begin{array}{c}\text { Archaeological Site } \\
\text { Factor }\end{array}$ & Geomorphology & \\
\hline \multicolumn{5}{|l|}{ Corinth } \\
\hline Agora & 0 & 0 & 0 & $\mathbf{0}$ \\
\hline Theatre & 0 & 0 & 0 & $\mathbf{0}$ \\
\hline Odeion & 0 & 0 & 0 & $\mathbf{0}$ \\
\hline Lechaion & 0.7 & 0.06 & 0.1 & 0.86 \\
\hline Kenchreai & 0.7 & 0 & 0.06 & 0.76 \\
\hline \multicolumn{5}{|l|}{ Kos } \\
\hline Neratzia Fortress & 0.7 & 0.12 & 0.06 & 0.88 \\
\hline Ancient Agora & 0.42 & 0.12 & 0.06 & 0.6 \\
\hline West Arch. Site & 0.28 & 0.12 & 0 & 0.4 \\
\hline Altar of Dionysus & 0.28 & 0.12 & 0 & 0.4 \\
\hline Asklepieion & 0 & 0 & 0 & $\mathbf{0}$ \\
\hline \multicolumn{5}{|l|}{ Samos } \\
\hline Heraion & 0.7 & 0 & 0.06 & 0.76 \\
\hline Roman Baths & 0.56 & 0 & 0.06 & 0.62 \\
\hline Eupalinos Tunnel & 0 & 0 & 0 & $\mathbf{0}$ \\
\hline Logothetis Castle & 0.21 & 0 & 0.05 & 0.26 \\
\hline \multicolumn{5}{|l|}{ Santorini } \\
\hline Akrotiri & 0 & 0 & 0 & $\mathbf{0}$ \\
\hline Ancient Thera & 0 & 0 & 0 & $\mathbf{0}$ \\
\hline
\end{tabular}

Table 3. Tsunami Susceptibility indicator weighted factors and scores for the archaeological sites under study. 
erarchy Process [Saaty 1987] with the assistance of M-MACBETH software [Bana e Costa et al. 2005] in order to address concerns about subjective transformation of qualitative judgments to numerical scores. The M-MACBETH software has been successfully applied in a number of studies for risk and vulnerability multi-criteria analysis of infrastructure to natural hazards such as earthquakes [Bana e Costa et al. 2008], tsunami [Dal'Osso et al. 2009, Tarbotton et al. 2012], and floods [Musungu et al. 2012]. The sum of selected factors via the weighted linear combination method composes a susceptibility indicator for each effect (Table 3 ).

The equally weighted sum of the susceptibility indicators expresses the Spatial Susceptibility Index (SSi) of each site to Earthquake Environmental Effects (Equation 1).

$$
S S i=\frac{L q S i|L s S i| T S S i}{3}
$$

The spatial susceptibility indicators and index scores are standardized linearly on a scale from 0 to 1 and expressed qualitatively through five susceptibility classes ranging from 'not susceptible' to 'very high susceptibility’ (Table 4).
The index score expresses the susceptibility of each archaeological site to the EEEs of ground liquefaction, landslides and tsunamis and its classification allows their relative prioritization at a national and regional level.

The temporal vulnerability indicators for the archaeological sites are expressed by factors that vary through time. These factors examine the physical vulnerability of the monuments that take account of intervention works that contribute to the resilience of the sites, the economic importance of the sites at a local and national level in terms of admission tickets and the human vulnerability in terms of annual visitor density (Table 5). Each factor's classes are standardized with linear scaled values ranging from 0 to 1 again following the Analytic Hierarchy Process [Saaty 1987].

The Temporal vulnerability index (TVi) represents an equally weighted sum of the physical vulnerability $(p)$, economic importance (e) and human vulnerability $(h)$ indicators (Equation 2 ) expressed by the intervention works, admission tickets and visitors density respectively.

$$
T V i=\frac{p|\varepsilon| h}{3}
$$

\begin{tabular}{|c|c|c|c|c|}
\hline Archaeological Sites & $\begin{array}{l}\text { Liquefaction indicator } \\
\qquad(L q S i)\end{array}$ & $\begin{array}{l}\text { Landslide indicator } \\
\qquad(\mathrm{LsSi})\end{array}$ & Tsunami indicator $(\mathrm{TsSi})$ & $S S i$ \\
\hline \multicolumn{5}{|l|}{ Corinth } \\
\hline Agora & 0.08 & 0.675 & 0 & 0.251 \\
\hline Theatre & 0.66 & 0.55 & 0 & 0.403 \\
\hline Odeion & 0.08 & 0.135 & 0 & 0.071 \\
\hline Lechaion & 1 & 0.425 & 0.86 & 0.76 \\
\hline Kenchreai & 0.96 & 0.335 & 0.76 & 0.684 \\
\hline \multicolumn{5}{|l|}{ Kos } \\
\hline Neratzia Fortress & 0.74 & 0.235 & 0.88 & 0.617 \\
\hline Ancient Agora & 0.695 & 0.175 & 0.6 & 0.489 \\
\hline West Arch. Site & 0.68 & 0.175 & 0.4 & 0.417 \\
\hline Altar of Dionysus & 0.62 & 0.115 & 0.4 & 0.377 \\
\hline Asklepieion & 0.03 & 0.74 & 0 & 0.256 \\
\hline \multicolumn{5}{|l|}{ Samos } \\
\hline Heraion & 0.80 & 0.275 & 0.76 & 0.610 \\
\hline Roman Baths & 0.9 & 0.175 & 0.62 & 0.564 \\
\hline Eupalinos Tunnel & 0 & 0.73 & 0 & 0.243 \\
\hline Logothetis Castle & 0.09 & 0.89 & 0.26 & 0.412 \\
\hline \multicolumn{5}{|l|}{ Santorini } \\
\hline Akrotiri & 0.26 & 0.505 & 0 & 0.248 \\
\hline Ancient Thera & 0 & 0.76 & 0 & 0.253 \\
\hline
\end{tabular}

Table 4. Regional distribution of the Spatial Susceptibility index for the archaeological sites under study. Sites under very high susceptibility to EEEs in bold. 
Again, the Temporal Vulnerability indicators and index are standardised in a linear manner on a scale from 0 to 1 and expressed qualitatively through five vulnerability classes ranging from 'not vulnerable' to 'very high vulnerability' (Table 5).

The Archaeological Site Vulnerability Index (A.S.V.I) for each archaeological site investigated is expressed by the equally weighted sum of the Temporal Vulnerability index (TVi) and the Spatial Susceptibility index (SSi), through Equation 3 expressed both quantitatively on a scale from 0 to 1 and qualitatively through 5 vulnerability classes ranging from 'not vulnerable' to 'very high vulnerability' (Table 4).

$$
\text { A.S.V.I. }=\frac{T V i \mid S S i}{2}
$$

nation of field surveys and the literature. Additional data were obtained from topographical 1:5000 maps, geological 1:50000 maps and local geotechnical surveys. The collection of data for the assessment of the temporal vulnerability was partly based on field surveys that included recording of the intervention works and admission tickets, while data regarding visitor densities were obtained from the official database of ELSTAT [2014].

\subsection{Spatial Susceptibility indicators}

In the following sections the factors that control the sensitivity of an archaeological site to ground deformation and comprise the indicators of ground liquefaction, landslides and tsunami are presented.

\begin{tabular}{|c|c|c|c|c|}
\hline Archaeological Site & $p$ & $e$ & $h$ & TVi \\
\hline \multicolumn{5}{|l|}{ Corinth } \\
\hline Ancient Agora & 0.77 & 1 & 1 & 0.923 \\
\hline Theatre & 1 & 0 & 0.33 & 0.443 \\
\hline Odeion & 0.75 & 0 & 0 & 0.25 \\
\hline Early Christian Basilica (Lechaion Harbour) & 0.75 & 0 & 0.33 & 0.36 \\
\hline Kenchreai Harbour Roman constructions & 0.75 & 0 & 0.33 & 0.36 \\
\hline \multicolumn{5}{|l|}{ Kos } \\
\hline Neratzia Fortress & 0.75 & 1 & 1 & 0.916 \\
\hline Ancient Agora & 0.65 & 0 & 0.33 & 0.326 \\
\hline West Archaeological Site & 0.5 & 0 & 0.33 & 0.276 \\
\hline Altar of Dionysus & 1 & 0 & 0.33 & 0.443 \\
\hline Asklepieion & 0.5 & 1 & 1 & 0.832 \\
\hline \multicolumn{5}{|l|}{ Samos } \\
\hline Heraion & 0.96 & 1 & 0.66 & 0.873 \\
\hline Roman Baths & 0.75 & 0 & 0.33 & 0.36 \\
\hline Eupalinos Tunnel & 0.75 & 1 & 0.66 & 0.803 \\
\hline Logothetis Castle & 0.5 & 0 & 0.33 & 0.276 \\
\hline \multicolumn{5}{|l|}{ Santorini } \\
\hline Akrotiri & 0.75 & 1 & 1 & 0.916 \\
\hline Ancient Thera & 0.91 & 1 & 0.66 & 0.856 \\
\hline
\end{tabular}

Table 5. Temporal vulnerability indicators and index for the archaeological sites under study.

The Archaeological Site Vulnerability Index method, summarized in Figure 2, represents a synthesis of the intrinsic susceptibility of a site's location (geological - geomorphological setting) to experience damage from earthquake environmental effects and its temporal physical, economic and social characteristics promoting the dynamic nature of archaeological sites vulnerability to earthquake hazard.

Geological and geomorphological data from each archaeological site was gained from a combi-

\subsubsection{Liquefaction susceptibility indicator (LqSi) factors}

Factors associated with the Liquefaction Susceptibility indicator mainly reflect the ease with which a saturated sedimentary deposit liquefies [Youd and Perkins 1978, Obermeier 2009] and include depositional environment (D.E.), water table depth (W.T.) and geological age of the deposits (A). However, since the liquefaction effect is characterised by recurrence during successive earthquakes [Youd 1984], archaeological sites founded on susceptible geological settings in 


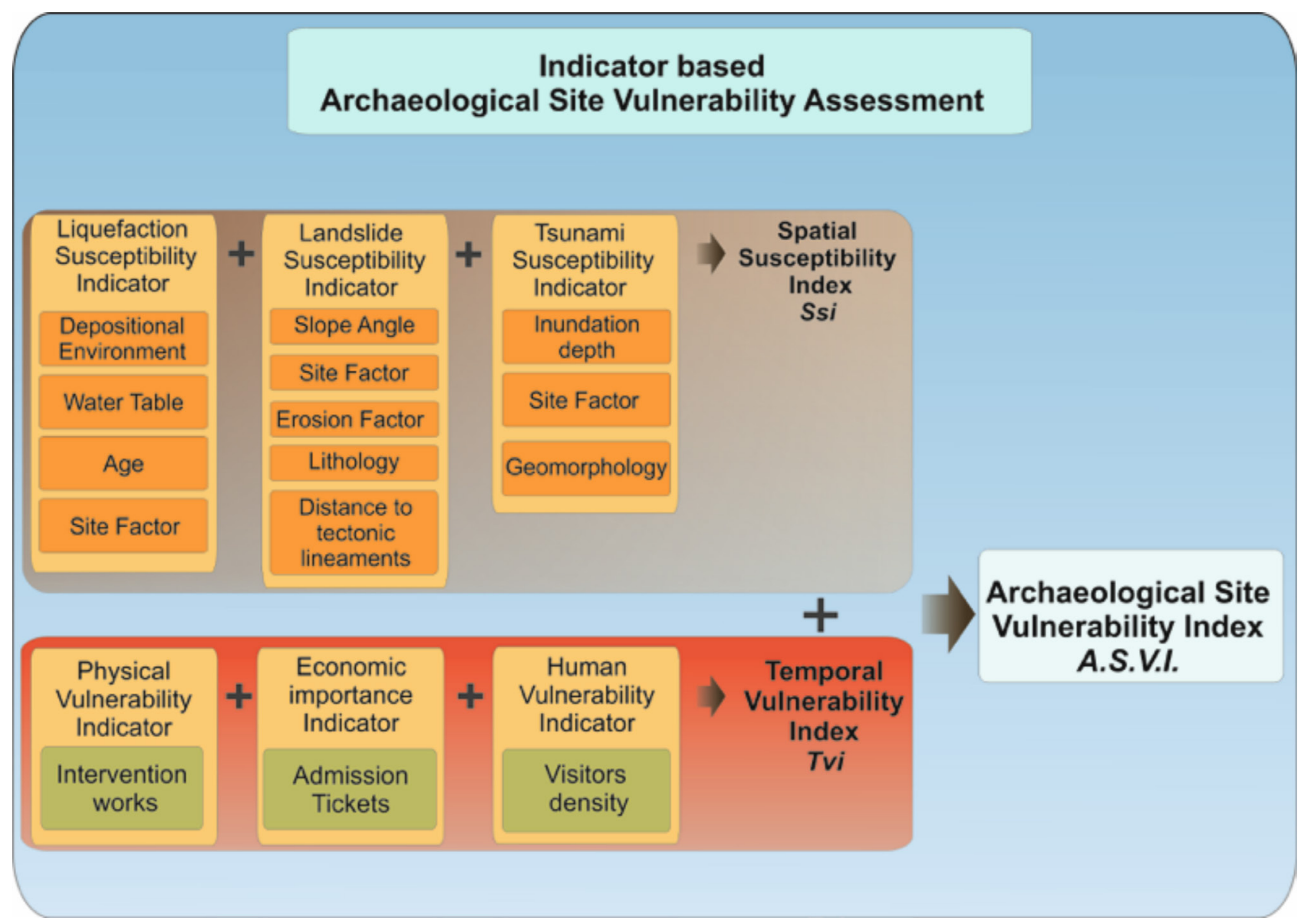

Figure 2. A schematic representation of the indicator based Archaeological Site Vulnerability Index.

regions characterised by active tectonics and intense seismicity, may preserve indications of ground instability and deformation from past liquefaction events. Therefore potential recurrence of liquefaction through archaeological site indications is taken into consideration and is introduced as the Archaeological Site Factor (S.F.).

The depositional environment factor (D.E.) is considered a key parameter since it determines the composition, sorting and degree of compaction of the deposits [Youd and Hoose 1977]. Deposits with greater sorting and looser compaction are considered as highly susceptible in contrast to clay-rich deposits with a fine content of $>15 \%$ that are generally considered having low susceptibility [Youd and Hoose 1977, Obermeier 2009]. The detailed susceptibility classification of depositional environments as proposed by Youd and Hoose [1977], Youd and Perkins [1978] and Youd [1998] (together with some necessary adjustments) have been grouped into three classes as presented in Table 2.

Saturation of the deposits is considered as another crucial parameter that contributes to their susceptibility to liquefaction [Youd 1998]. The susceptibility that characterizes deposits decreases with increasing water table depth [Obermeier et al. 1990, Youd and Hoose 1977, Youd 1998] since liquefaction resistance increases with overburden pressure and age of sediment, both of which generally increase with depth. Saturation is expressed by the water table depth factor (W.T.) combined with qualitative judgments by Youd, [1998].

The geological age (A) of the deposits is another parameter that according to Youd and Hoose [1977] contributes to a site's susceptibility to ground liquefaction. The susceptibility of deposits decreases with age since they become more consolidated and therefore less prone to liquefaction. In this study, the susceptibility of sedimentary deposits in relation to their geological age is made according to the qualitative classification of Youd and Perkins [1978]. Since the study concerns archaeological sites that date from the mid to late Holocene, the age class of $<500$ years is merged with the Holocene class and is characterised as highly susceptible [Obermeier 2009]. Thus, three geological periods are set as classes for the Age factor, the Holocene period with high susceptibility, the Pleistocene period with potential susceptibility and the Pre-Pleistocene period as not susceptible.

Finally, direct and/or indirect effects preserved in archaeological sites that could potentially relate to past ground liquefaction events provide useful information for their susceptibility assessment although further 
field investigations are considered necessary. These parameters are summarized in order of importance as:

i) Relevant studies (R.S.) - Since liquefaction phenomenon tends to recur at the same site during successive earthquakes, archaeological sites with records and/or published studies on past earthquake induced liquefaction events and deformation are considered as susceptible to ground liquefaction during future earthquakes [Youd 1984b].

ii) Ground deformation (G.D.) - indirect structural indications from potential Earthquake Archaeological Effects (EAEs) attributed to ground deformation [Rodríguez-Pascua et al. 2011] that could relate to the surface expression of ground liquefaction. Such effects include circular and linear depressions or buckling structures in mortar, regular or irregular pavements. Although these archaeoseismological effects are considered as off-fault geological effects, caution is necessary for most of the archaeological sites are characterised by a long history of use, suggesting successive and extensive anthropogenic layers. Therefore, similar effects such as compaction and settlement of artificial fill due to seismic activity could be misinterpreted as ground liquefaction indications. This uncertainty should be taken into consideration in the attributed ranking scores.

iii) Stabilization works (S.W.) - The presence of slope stabilization works such as retaining or buttress walls can also be considered as an indirect indication of mitigation works against ground instabilities. However, further field survey and studies are necessary to search for Earthquake Archaeological Effects of ground deformation structures and/or strain structures on the building fabric indicative of ground liquefaction [Rodríguez-Pascua et al. 2011].

\subsubsection{Landslide Susceptibility indicator (LsSi) factors}

Earthquake induced landslides have been studied extensively for historic and contemporary events. Analysis has focused on the identification and assessment of the relation between geological and seismological parameters to slope failures [Keefer 1984, Rodríguez et al. 1999, Keefer 2002]. Statistical analysis of earthquake induced landslide distribution data from the 1989 Loma Prieta California event resulted in Keefer [2000] suggesting that landslide concentration has a strong inverse correlation with distance from earthquake source and a positive correlation with slope steepness. Additionally, it is suggested that regional-scale variations in the hazard level of seismically induced landslides, are more efficiently correlated with geological and geomorphological characteristics rather than with geotechnical parameters (shear strength, pore-water pressure etc).

In this study, the term landslide is based on the terminology of Varnes [1984]. However, it does not include landslides caused by liquefaction and lateral spread since they are studied separately. Assessment of potential landslide volume and run out is also not included. Although different landslide types take place under different geological and geomorphological conditions, this study focuses on identifying locations within the archaeological sites that are more susceptible to slope instabilities from factors such as i) slope angle (S.A.), ii) archaeological site indications (S.F.), iii) erosion (E), iv) lithology (L) and v) distance from tectonic lineaments (D.T.L.).

Taking into consideration landslide susceptibility studies in Greece, their scale (1:50.000 and national scale), landslide types under study, classifications, limitations and the international literature on earthquake induced landslides, slope angle (S.A.) was classified into four classes with the highest class being that of $>30^{\circ}$ (Table 2) including slopes and escarpments susceptible to both landslides and rock falls. Class scores are based on the standardization of the Landslide Relative Frequency proposed by Sabatakakis et al. [2013].

The Archaeological Site Factor (S.F.) introduced in this study represents the inventory of the site through the following direct and indirect parameters relating to slope instabilities scored according to their relative importance to the effect of landslides:

i) Slope instability - Relevant Studies (S.I. - R.S.) - Direct indications of existing slope instability at the site, through observations, records and relevant studies represent the inventory of the site. Indicators mainly include rock-falls, ground cracks and slope deformation that are considered as direct indications of existing slope instability.

ii) Indirect indications of slope instability come from the monuments of the site. Tilted or folded walls, rotated and displaced buttress walls are considered as Earthquake Archaeological Effects (EAEs) indicative of permanent ground deformation [Rodríguez-Pascua et al. 2011]. These effects need to be handled with caution 
since similar effects such as compaction of artificial fill could be misinterpreted for slope instability indication. Therefore, these indications are assessed during fieldwork and where they can be related to slope instability they should be included in the study.

iii) Slope stabilization works (S.W.) - If an archaeological site is indicative of landscape modification through quarrying and artificial fill relating to levelling of slopes then such interventions usually include retaining walls and buttress walls. If no strain structures are observed, their presence indicates actions for slope stabilization and they should be included in the study. However, if these constructions are indicative of strain structures on the building fabric generated by permanent ground deformation relating to slope instability then they potentially represent EAEs of slope instability.

The erosion factor (E) represents an indirect indication of slope instability that relates to erosion processes that act as triggering parameters for instabilities in coastal slopes and continental slopes near streams. The factor reflects the proximity of an archaeological site to the coastline and/or stream that combined with the slope angle and lithology are indicative of potential slope instabilities In this study, a combination of the Distance to Coast Factor by Alves et al. [2011] for a 1:10.000 scale and the distance from streams factor by Kouli et al. [2014] expressed through five classes is proposed.

The lithology factor $(\mathrm{L})$ is based on the susceptibility of lithological units as classified and applied in the landslide susceptibility map of Greece [Sabatakakis et al. 2013 and references therein]. The flysch unit presents the highest frequency and can be considered as the most susceptible unit to slope instabilities followed by Neogene sediments and recent deposits. The units with the lowest frequency that can be considered as low susceptibility units are carbonates, metamorphic rocks and igneous volcanic rocks. These units are merged into six classes ranked and standardized according to the Landslide Relative Frequency of the national inventory.

Finally, the distance to tectonic lineaments factor (D.T.L.) reflects the effects of active tectonics on the stability of slopes. Fracturing and shearing of geological formations by active tectonic processes contribute significantly to slope failures since they are associated with extensive fractured zones and steep relief morphology. Landslide susceptibility studies in Greece are characterised by a variety of classes and linear ratings for this factor [Foumelis et al. 2004, Ladas et al. 2007, Rozos et al. 2011, Kouli et al. 2014]. However, for this study the classification and scores by Ladas et al. [2007] are applied since the classes are distributed in a way that express satisfactorily the mean tectonic shear attenuation with distance.

\subsubsection{Tsunami Susceptibility Indicator (TsSi) factors}

The susceptibility of a coastal area to geomorphological impacts from a tsunami mainly depend on coastal geomorphological and topographical factors that according to the literature have an effect on tsunami run-up, inundation depth and backwash dynamics that control the extent of the impacts [Dawson 1994, Matsutomi et al. 2001, Choowong et al. 2007, Goto et al. 2011]. Tsunami run-up and inundation dynamics vary significantly from site to site and studies have shown that the main controlling parameters are crustal deformation during the seismic event, orientation of propagation vector to the mean shoreline direction, distance from the tsunami generation area, bathymetry, coastal and land morphology [Geist 2001, Papathoma and Dominey-Howes 2003, Fritz et al. 2011, Lekkas et al. 2011]. In this study, the tsunami propagation vector is considered as having maximum value, oriented at right angles to the mean shoreline and factors of coastal and land geomorphology will be assessed according to their contribution to on-shore tsunami propagation and impact.

The susceptibility of an archaeological site to tsunami is expressed through topographical and geomorphological properties reflecting the potential of the site to experience the impacts from a tsunami. This potential is further investigated and supported by records of historical or modern tsunami events for each site. In the following paragraphs, the factors and their classes used in this study are presented in order of importance.

The inundation depth factor (I.D.) represents a combination of international emergency planning practices with studies performed at a local level, based on historical records of tsunamis in Greece. The $10 \mathrm{~m}$ contour is generally considered as the mean maximum altitude of potential tsunami inundation depth [Samant et al. 2008, Lekkas et al. 2010] with the first $5 \mathrm{~m}$ contour as the most susceptible zone for tsunami inundation, [Papathoma and Dominey-Howes 2003]. At this point it has to be mentioned that setting the 10 $\mathrm{m}$ elevation as a potential maximum for tsunami runup height and inundation depth represents a general 
estimation given that higher elevations of run-up and inundation have been recorded regionally (e.g. in Astypalaea by the 1956 Amorgos tsunami, Dominey-Howes [1996]), and internationally (e.g. in Tohoku by the 2011 earthquake tsunami Mori et al. [2011]). However, these higher altitudes are considered as exceptional and locally recorded and are not included in this study in order to allow a more detailed analysis for the coastal zone. Therefore the classification as presented in Table 2 includes six classes from $0-2 \mathrm{~m}$ to $>10 \mathrm{~m}$ with scores ranging from very high (1) to not susceptible (0).

The catalogues of historical seismicity and tsunamis provide information on whether an archaeological site has suffered tsunami impacts. However, the Greek catalogues of historical tsunami events include gross errors and inaccuracies that may lead to incorrect assumptions about the return periods and magnitudes of tsunami events [Dominey-Howes 2002, Papadopoulos and Fokaefs 2005]. Studies that combine systematic investigations of the available documentary and geological records, combined with bathymetric data and modelling of tsunami propagation, run-up and inundation represent the most reliable sources for historical tsunami events, [Dominey-Howes 2002]. Indirect indications for historical tsunami events come from published studies investigating high-energy deposits that potentially could relate to past tsunami events. After the events of the Indian Ocean 2004 and Tohoku, Japan 2011, an increase in paleotsunami studies in the Mediterranean is recorded [Morhange et al. 2012]. Greek coastlines and archaeological sites have been studied systematically for high-energy deposits that are correlated with historical seismic events and are assessed as tsunami deposits. However, the relation of high-energy deposits with tsunami deposits is a challenging task requiring extensive sedimentary, geoarchaeological, archaeoseismological studies and multidisciplinary expert judgements. Therefore, studies that suggest high energy events for an archaeological site that potentially relate to a tsunami event that is not included in the historical catalogues although they should be taken into consideration, should be treated with caution. Consequently, the Archaeological Site Factor (S.F.) for this effect is composed by three classes summarised to i) historical records and relevant studies that support the validity of the historical record, ii) historical record without relevant studies and iii) high energy event studies that although they correlate with historical seismic events, they do not correlate with historical tsunami records.

Finally, recent post-tsunami studies indicate a di- rect relationship between run-up, inundation, degree of sediment deposition and erosion with coastal geomorphology [Goto et al. 2011, Chandrasekar et al. 2012, Tanaka et al. 2012]. Tsunami impacts are controlled mainly by the coastal configuration and local geographic setting with maximum run up and inundation extent along estuarine coasts and minimum runup and inundation along elevated coasts suggesting that steep topographic coastal settings are less affected in relation to estuarine coastal settings that are highly affected. Therefore, the geomorphological setting of a site can be considered indicative of its susceptibility to run-up and inundation extent and subsequently to potential geomorphological impacts. In this study, the Geomorphology factor $(G)$ is based on the quantitative statistical data provided by the study of Chandrasekar et al. [2012] for the relationship between inundation and coastal geomorphology.

\subsection{Temporal Vulnerability indicators}

Assessment of the temporal vulnerability of archaeological sites is in part, built upon the extensive range of vulnerability assessment parameters proposed by Papathoma-Köhle et al. [2007], and go further to include the physical state of monuments at our study sites, combined with economic data for those sites as well as visitor density.

\subsubsection{Physical vulnerability indicator $(p)$}

The physical vulnerability of the monuments for each archaeological study is explored via an identification, analysis and assessment of the existing range and state of intervention works that have been undertaken to date. Intervention works on archaeological sites as defined in the charters of Athens 1931 [CIAM 1931], Venice 1964, [ICOMOS 1965] and Burra 2013 [Australia ICOMOS 2013], range in style from a 'minimum rescue conservation work' to 'extended reconstructions of monuments for their public use as museums, galleries and so forth'. More specifically, the types of interventions include:

- Conservation: Temporal consolidation and stabilization interventions aimed at the short-term preservation and protection of the monument from further damage or even the loss of it, in a non-invasive way [ICOMOS 2001, Mallouchou-Tufano 2007, Australia ICOMOS 2013].

- Restoration: The process of restoration aims to preserve and reveal the aesthetic and historic value of the monument [ICOMOS 1965]. It involves archaeological and historical study of the monument, and structural stability analysis. Ad- 
ditions are not allowed and replacement of missing parts must integrate harmoniously with the whole, but at the same time they must be distinguishable from the original [ICOMOS 2001].

- Anastylosis: The term designates specific types of interventions on monuments preserved in a ruined condition, in order to, wherever possible, reinstate any original fragments that may be recovered [CIAM 1931]. New materials used for this purpose should in all cases be recognizable.

- Reconstruction: The total or to a considerable percentage recreation of a vanished monument using new materials [Mallouchou-Tufano 2007, Australia ICOMOS 2013].

Recent investigations on the effectiveness of restoration interventions for the vulnerability reduction of masonry structures to seismic hazard are significant. They suggest that before restoration interventions, the fragility curves of a historical structure in Greece would be expected to result in 'a $71 \%$ probability of experiencing heavy damage from a seismic motion with demand represented by $P G A=0.20 g^{\prime}$. However, after restoration interventions the probability of damage was reduced to $40 \%$ [Asteris et al. 2014]. We note however, more empirical work is needed at a wider range of archaeological sites and on a much greater range of structures to determine the effectiveness or otherwise of mitigative strategies.

Therefore, the extent of interventions on a monument is considered as a factor that reflects the monument's physical vulnerability in the sense that a monument with no interventions is considered as neglected and therefore more susceptible to further deterioration and potential damage from a future earthquake event, and is assigned the score of 1 . On the contrary a monument that has received extensive interventions (reconstructions) is considered as being relatively safe for future generations and is considered as relatively resilient and is assigned the score of 0 . Although we acknowledge that in reality this is heavily dependent on the quality of the work undertaken. For an archaeological site, each monument is assigned with a score according to the type of interventions that it preserves. The sum of the scores assigned, divided by the number of the monuments represent the physical vulnerability indicator for the archaeological site. Monuments preserved in a buried condition are not included in the study.

\subsubsection{Economic importance indicator (e)}

The importance of an archaeological site to the national and local economy is indirectly assessed through the factor of admission tickets. There are
3,080 archaeological sites in Greece with 117 sites having admission by ticket sales [ELSTAT 2014] indicating that the majority of the archaeological sites of the country are unexploited. However, the majority of these unexploited sites are open to the public without admission ticket. The main reason why so many sites in Greece are open to the public without admission is due to the fact that they have not yet been promoted, do not follow the appropriate installations standards (information signs, routes, WC, etc.) and are not assigned with the necessary personnel.

Therefore, archaeological sites with admission tickets can be considered as valuable sites to the national economy and are scored with the value of 1 . In the case of an earthquake, potential damage to the monuments will keep the sites closed to the public for a considerable time period in order to restore the damaged monuments, resulting in direct financial impacts on both the local and national economy. On the other hand, the sites that are open to the public without admission ticket, or totally closed to the public, will have no direct economic impacts to the national economy in the event of their damage, and are assigned with the value of zero. At this point, it should be stated that sites without admission although they do not contribute to the national economy are not considered as less "valuable" compared to the sites with admission. The "value" of the cultural heritage in terms of archaeological, social and economic dimensions is not examined in this study. All monuments are considered as unique having equal archaeological, social and economic value.

\subsubsection{Human vulnerability indicator (h)}

This indicator is based on the relative density that the archaeological sites present according to their number of visitors per year, indirectly expressing the human vulnerability through potential injuries or casualties during a seismic event. In order to investigate the relative density of the archaeological sites for 2013, from the 117 archaeological sites of the country with admission tickets the density distribution was examined and classified according to the data available from ELSTAT [2014] (Table 6). The classification indicates that nearly half of the archaeological sites $(42 \%)$ present the minimum density with less than 10.000 visitors per year, while approximately one third of the archaeological sites have annual visitor density ranging from 10.000 to 100.000 . Sites with density higher than 100.000 visitors represent $17.7 \%$ while only 12 archaeological sites, representing approx- 
imately $10 \%$, were kept closed to the public. The sites closed to the public are either due to direct safety issues, or due to ongoing intervention and promotion works.

For the majority of the archaeological sites open to the public without admission tickets, no information on visitor density is available. Since it is not possible to estimate the number of visitors for the open archaeological sites, taking into consideration that they are not favored by organized group visits and receive only individuals, they are classified in the class of $<10.000$ visitors per year, although small variations may in reality exist. Taking

\begin{tabular}{lccc}
\hline Archaeological Sites & SSi & TVi & A.S.V.I \\
\hline Corinth & & & \\
\hline Agora & 0.125 & 0.458 & 0.583 \\
Theatre & 0.201 & 0.221 & 0.423 \\
Odeion & 0.035 & 0.125 & 0.160 \\
Lechaion & 0.38 & 0.125 & 0.505 \\
Kenchreai & 0.342 & 0.18 & 0.522 \\
\hline Kos & & & \\
\hline Neratzia Fortress & 0.308 & 0.458 & 0.766 \\
Ancient Agora & 0.244 & 0.163 & 0.407 \\
West Arch. Site & 0.208 & 0.138 & 0.346 \\
Altar of Dionysus & 0.188 & 0.221 & 0.41 \\
Asklepieion & 0.128 & 0.416 & 0.544 \\
\hline Samos & & 0.138 & 0.344 \\
\hline Heraion & 0.305 & 0.436 & 0.741 \\
Roman Baths & 0.282 & 0.18 & 0.462 \\
Eupalinos Tunnel & 0.121 & 0.401 & 0.523 \\
Logothetis Castle & 0.206 & 0.458 & 0.554 \\
\hline Santorini & & & \\
\hline Akrotiri & & & \\
Ancient Thera & & & \\
\hline & & & \\
\hline
\end{tabular}

Table 6. Archaeological Site Vulnerability Index (A.S.V.I.)scores for the sites under study.

into consideration that the higher the density of visitors the higher the human vulnerability, then the standardized scores presented in Table 6 were assigned to the visitors density classes.

\section{Results - Discussion}

The application of the proposed method to the selected archaeological sites produced a considerable amount of data. The results of the assessment provide useful information that can be used to consider the range of potential risk management and preservation options available to authorities to protect sites of cultural heritage. Further, they also allow the identification of aspects of the method that should be subject to further analysis and investigation, modification and improvement and field-testing at other sites to determine its general applicability. Where appropriate, we draw attention to these opportunities. In the following sections the results are presented in a graphical manner while the weighted factors, indicators and index scores for each site are summarized in tables included in the Appendix.

\subsection{Spatial Susceptibility}

\subsubsection{Liquefaction Susceptibility}

The results of the LqSi suggest that three sites present exceptionally high scores of susceptibility to ground liquefaction ranging from 0.9 to 1 (Figure 3). These are Lechaion harbour and the Kenchreai harbour in Corinth and the Roman Baths in Samos. The maximum score of 1 , attributed to Lechaion harbour, is the result of the highly susceptible setting and a study on past liquefaction events [Minos-Minopoulos et al. 2015]. Kenchreai harbour is the second most susceptible site with a score of 0.96 followed by the Roman Baths (0.9) (Table 1). The slight deviation of its score in relation to Kenchreae harbour's score is mainly due to the lack of archaeological site indications. Heraion in Samos is another site with a very high susceptibility (0.8) but relatively less susceptible than Lechaion, Kenchreae and the Roman Baths, mainly attributed to its depositional environment that is composed of sandy silts representing an alluvial plain environment. The very high susceptibility scores suggest that these sites should be prioritised in the near future for geotechnical investigations so that appropriate mitigation measures may be identified.

The majority of the archaeological sites in Kos (Neratzia Fortress (0.74), Ancient Agora (0.695), West Archaeological site (0.68), and the Altar of Dionysus (0.62)) and the Theatre in Corinth (0.66) are the sites with high liquefaction susceptibility that is attributed mainly to their deposits, age and water table depth.

Akrotiri on Santorini is the only site with a low susceptibility indicator of 0.26 . This is the result of a geological age factor score of 0.2 and archaeological site factor score of 0.06, while the sites of Agora and Odeion in Corinth, the Asklepieion in Kos, the Eupalinos tunnel and Logothetis Castle in Samos and the Ancient Thera in Santorini are considered as not susceptible since their spatial properties do not favour the manifestation of the effect.

It is interesting to note that no site is characterised by moderate susceptibility and this is either 


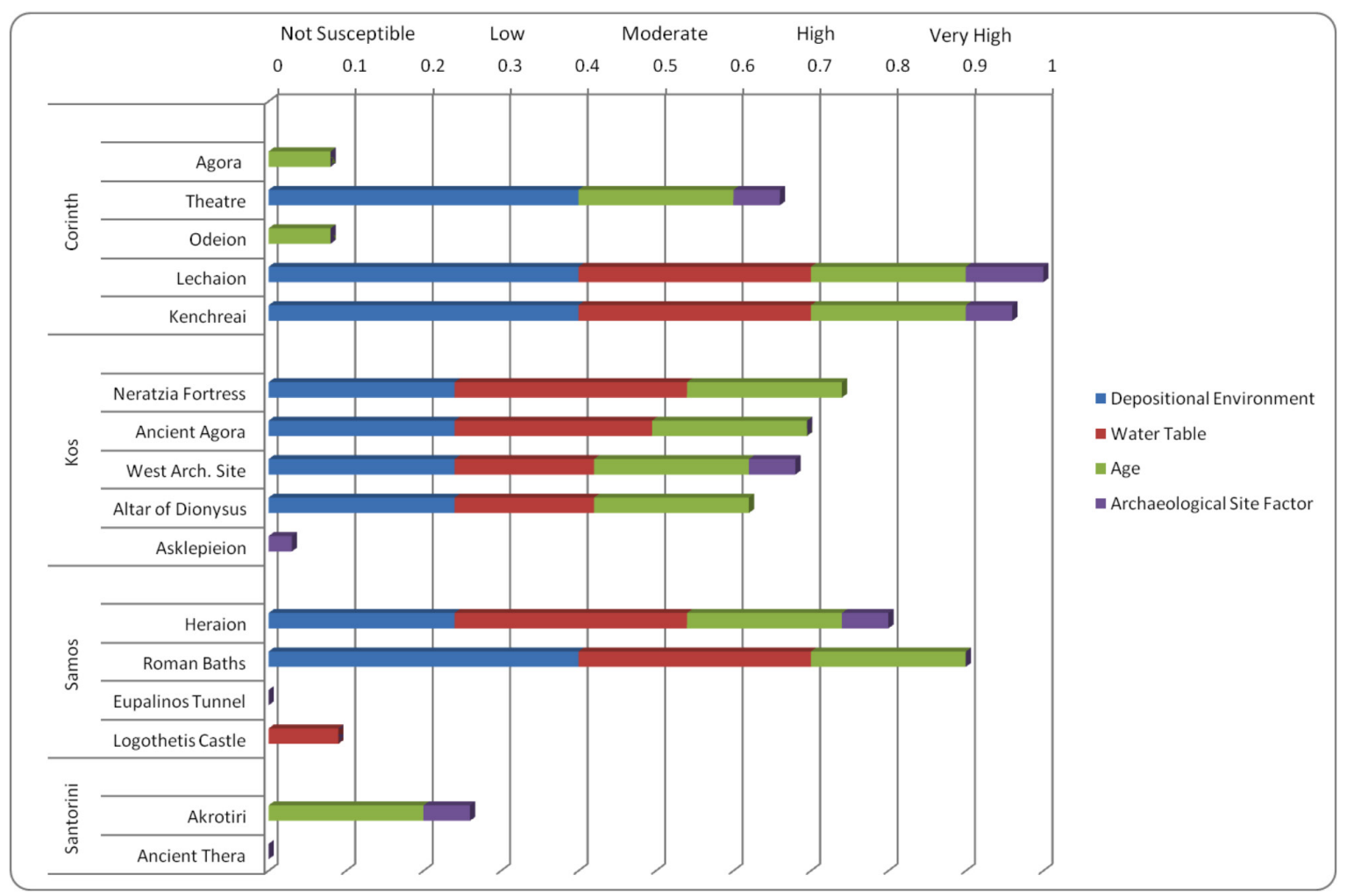

Figure 3. The Liquefaction Susceptibility indicator diagram for the archaeological sites under study.

attributed to the geological - geomorphological setting of the sites or it indicates that the indicator requires further refinement.

Further application of the LqSi to new archaeological sites coupled with analysis at sites similar in form will allow resolution of this issue.

\subsubsection{Landslide Susceptibility}

The application of the LsSi for the assessment of landslide susceptibility suggests that the archaeological site with the highest susceptibility is the Logothetis Castle, Samos Island with a score of 0.89 (Figure 4). The site is located on a coastal escarpment reflecting

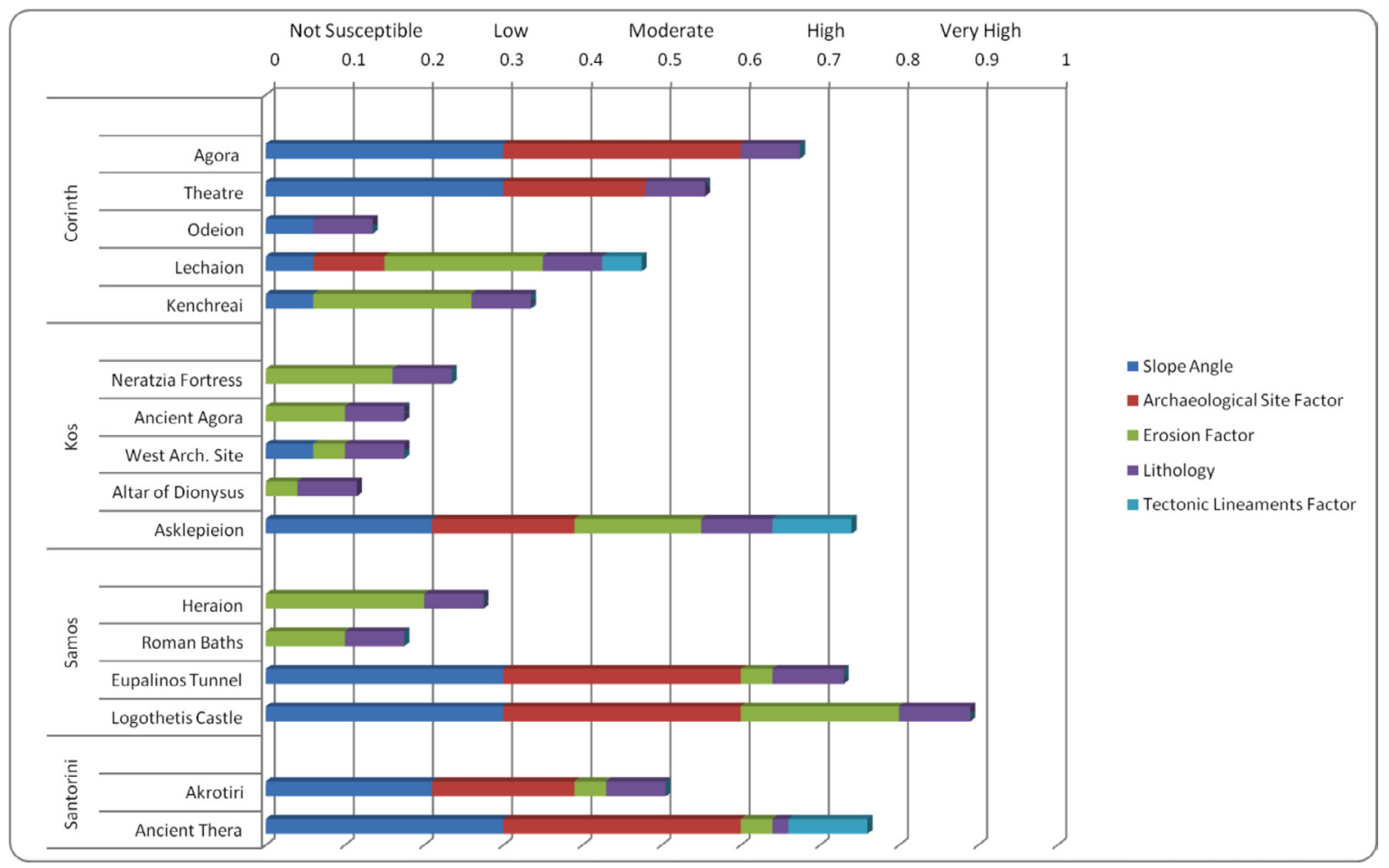

Figure 4. The Landslide Susceptibility indicator diagram for the archaeological sites under study. 

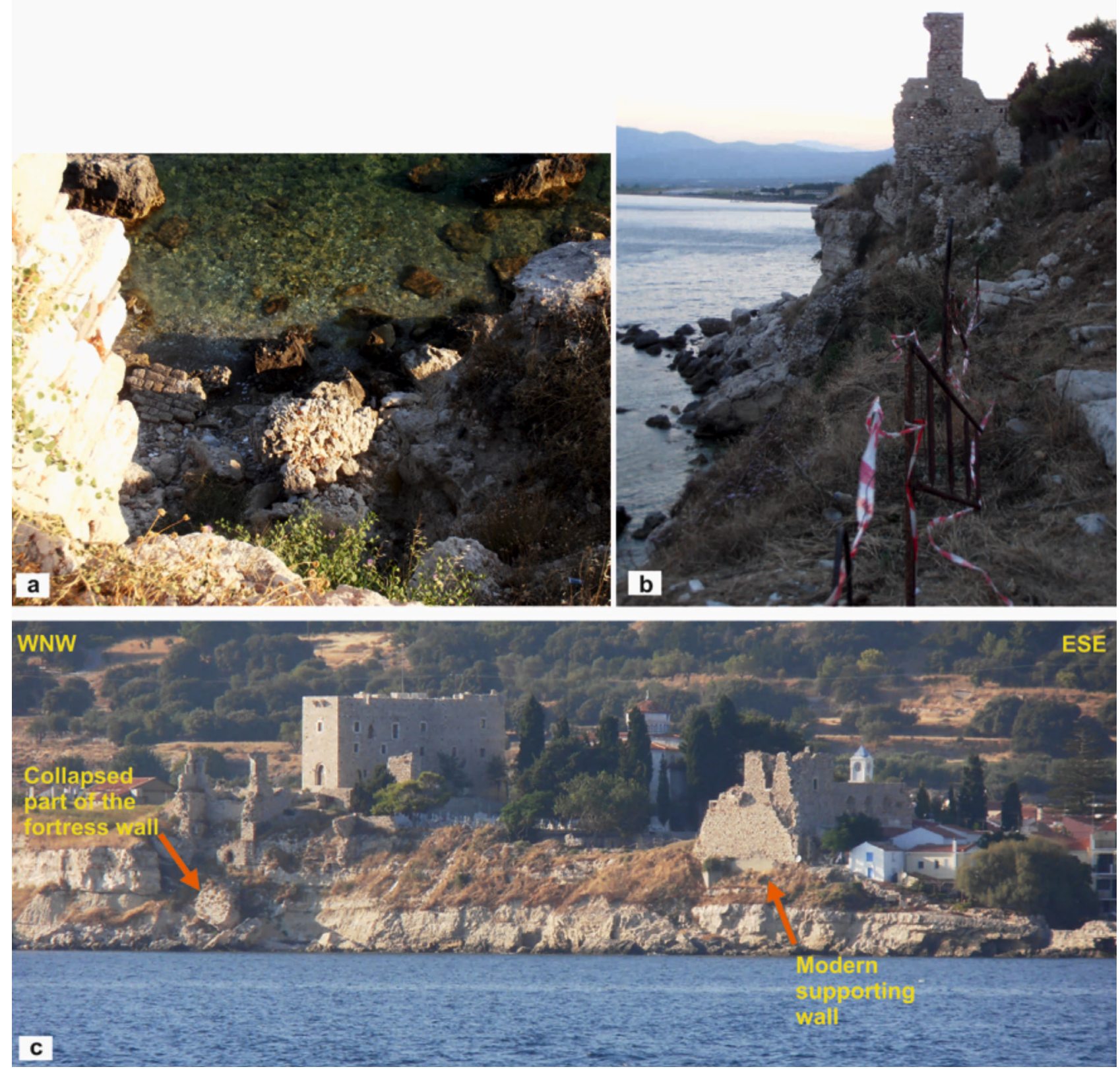

Figure 5. Slope instabilities as recorded on the southern escarpment at Logothetis Castle site (a) collapsed part of the fortress wall along with rock fall debris deposits (b) the active escarpment and the WNW fortress tower with debris deposits, (c) the preserved remains of the WNW and ESE towers of the fortification wall.

the intense coastal erosion processes on the Neogene marly limestone formation (Figure 5). This escarpment presents extensive slope instabilities that have led to the gradual collapse of the southern fortress wall and to extensive structural effects on the fortress towers. Therefore, it can be suggested that a future seismic event might trigger rapid and extensive rock-falls along the unstable and deteriorated escarpment front, resulting to further damage on the fortress wall towers.

The archaeological sites of Agora in Corinth, the Asklepieion in Kos, the Eupalinos tunnel in Samos and Ancient Thera in Santorini are classified as sites with high susceptibility that require further studies of a geo- technical nature that will assess their susceptibility in detail (Table 2). Better underlying knowledge of geotechnical aspects of each site would help to refine aspects of the method and increase confidence in the attribution and weighting of factors used in our assessment.

The ancient harbour of Lechaion, the Theatre in Corinth and Akrotiri in Santorini are rated as sites with moderate susceptibility mainly attributed to their slope angles, archaeological indications and erosion processes. They also require further studies for the detailed assessment of their susceptibility. However, priority should be given to the sites with very high and high susceptibility. Finally, the Kenchreai harbour in 
Corinth, the Neratzia Fortress in Kos and the Heraion in Samos, are classified as sites with low susceptibility. Their scores mainly reflect their gradual deterioration from coastal erosion processes that require direct measures for their preservation.

\subsubsection{Tsunami Susceptibility}

The results of the TsSi (Table 3 ) are indicative of two sites that present the highest susceptibility to tsunami impacts. These are the Lechaion harbour in Corinth (0.86) and the Neratzia fortress in Kos (0.88) (Figure 6). Although both sites are located at 0-2 m elevation, Lechaion harbour is considered as more susceptible to tsunami effects since it is located in an estuary. For the site of Neratzia fortress, the historical tsunami record of the A.D. 554 event suggests that the area suffered extensive damage, although the event pre-dates the construction of the fortress. For the Lechaion harbour although no historical tsunami records exist, recent studies suggest high-energy deposits that relate to tsunami events are present [Hadler et al. 2013].

Kenchreai harbour in Corinth and Heraion site in Samos share the same score of 0.76 and are classified as highly susceptible to tsunami. Both sites are located in the 0-2 $\mathrm{m}$ inundation depth zone and they are characterised by shallow coastal geomorphology. The Roman Baths site in Samos (0.62) and the Ancient Agora in Kos (0.6) are additional sites character- ised by high susceptibility to tsunami impacts mostly due to the inundation depth zones of higher altitude.

The West archaeological site and the Altar of Dionysus (0.4) are characterised as moderately susceptible mainly due to their location to higher altitudes and due to the historical tsunami record. Finally, the Logothetis Castle in Samos (0.26) is considered as a site of low susceptibility. This score reflects the low inundation depth factor score and the low geomorphology score since the site is located on an elevated coast at $10 \mathrm{~m}$ altitude.

Assessment and refinement of factors impacting tsunami susceptibility could be improved down the track by benchmarking actual damage states observed in future post-tsunami surveys to structures with similar characteristics as those contained in our assessment. This would greatly increase confidence in the way in which we have deployed our method or provide insights for improvement and enhancement.

\subsubsection{Spatial Susceptibility index}

Synthesis of the spatial susceptibility through the Spatial Susceptibility index highlights the archaeological sites of Lechaion and Kenchreai harbours in Corinth, Neratzia Fortress in Kos and Heraion in Samos as the most susceptible sites to secondary Earthquake Environmental Effects (Figure 7). Their high susceptibility is mainly attributed to their coastal settings and depositional environ-

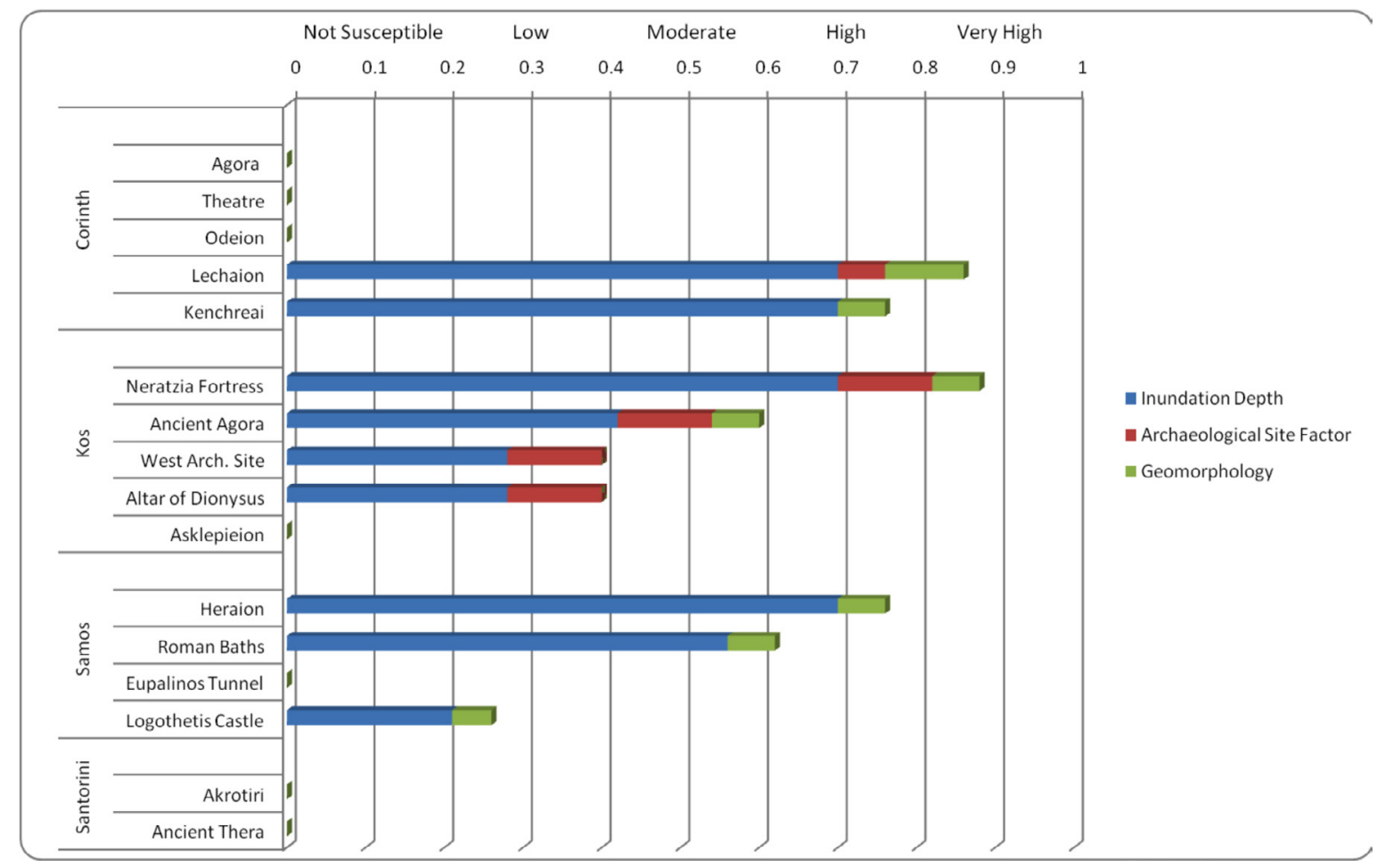

Figure 6. The Tsunami Susceptibility indicator diagram for the archaeological sites under study. 


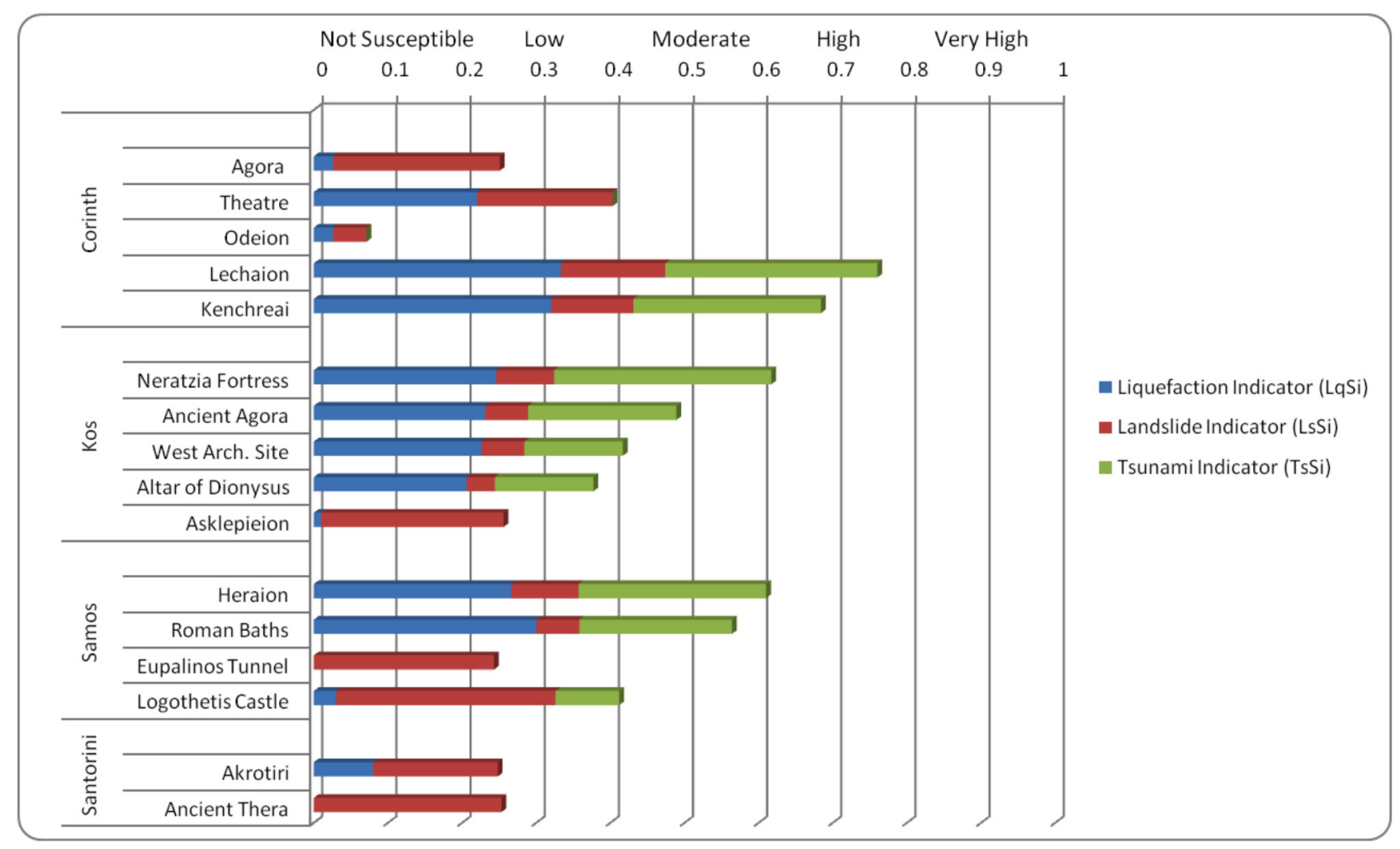

Figure 7. The Spatial Susceptibility index for the archaeological sites under study (modified after Minos-Minopoulos et al., 2016).

ments that in combination with poor geotechnical properties, favour the manifestation of ground liquefaction and on shore tsunami impacts.

Moderate index values characterise sites susceptible to at least one effect or a combination of susceptibilities to more than one effect (Table 4 in the Appendix). For example, the site of Logothetis Castle in Samos (0.412) is highly susceptible to landslide and presents low susceptibility to tsunami, while the Ancient Agora in Kos (0.489) presents high susceptibility to liquefaction and tsunami, and low susceptibility to landslides.

Finally, sites with low susceptibility reflect sites susceptible to one effect only - that of landslides - attributed mainly to the location of the sites at higher altitudes, to the geological properties of the substratum and archaeological indications of ground instabilities. The Odeion in Ancient Corinth is the site with the lowest index (0.071) that is considered as not susceptible to secondary EEEs.

Although the susceptibility indicators highlighted archaeological sites with very high susceptibility, the SSi indicates that no site is characterised with very high susceptibility. This is attributed to the fact that in order for a site to have very high spatial susceptibility, it must present high or very high susceptibility to all three EEEs, a condition that can be considered as exceptional and was not encoun- tered during the field surveys on the sites.

Future refinement and improvement of the SSi could occur by integrating the results of new scientific studies as they emerge. Thus, the development of the method should be a reflective and on-going process always seeking to integrate latest knowledge.

The results from the application of the Spatial Susceptibility index suggest that the majority of the archaeological sites investigated by us are susceptible to at least one secondary EEE highlighting the contribution of spatial aspects to the vulnerability of archaeological sites to earthquake hazard and the necessity for their integration in seismic vulnerability and risk assessments for cultural heritage protection. Furthermore, the method allows the systematic evaluation of spatial susceptibility for archaeological sites, their comparison (Figure 7) and a guide for prioritizing sites for further investigations and mitigation measures at a regional and national level.

\subsection{Temporal vulnerability}

\subsubsection{Physical vulnerability}

From the application of the physical vulnerability indicator (p), the archaeological sites of Heraion in Samos (0.96), Ancient Thera in Santorini (0.91), the Theatre in Corinth (1) and the Altar of Dionysus in Kos (1), stand out as the sites with the 


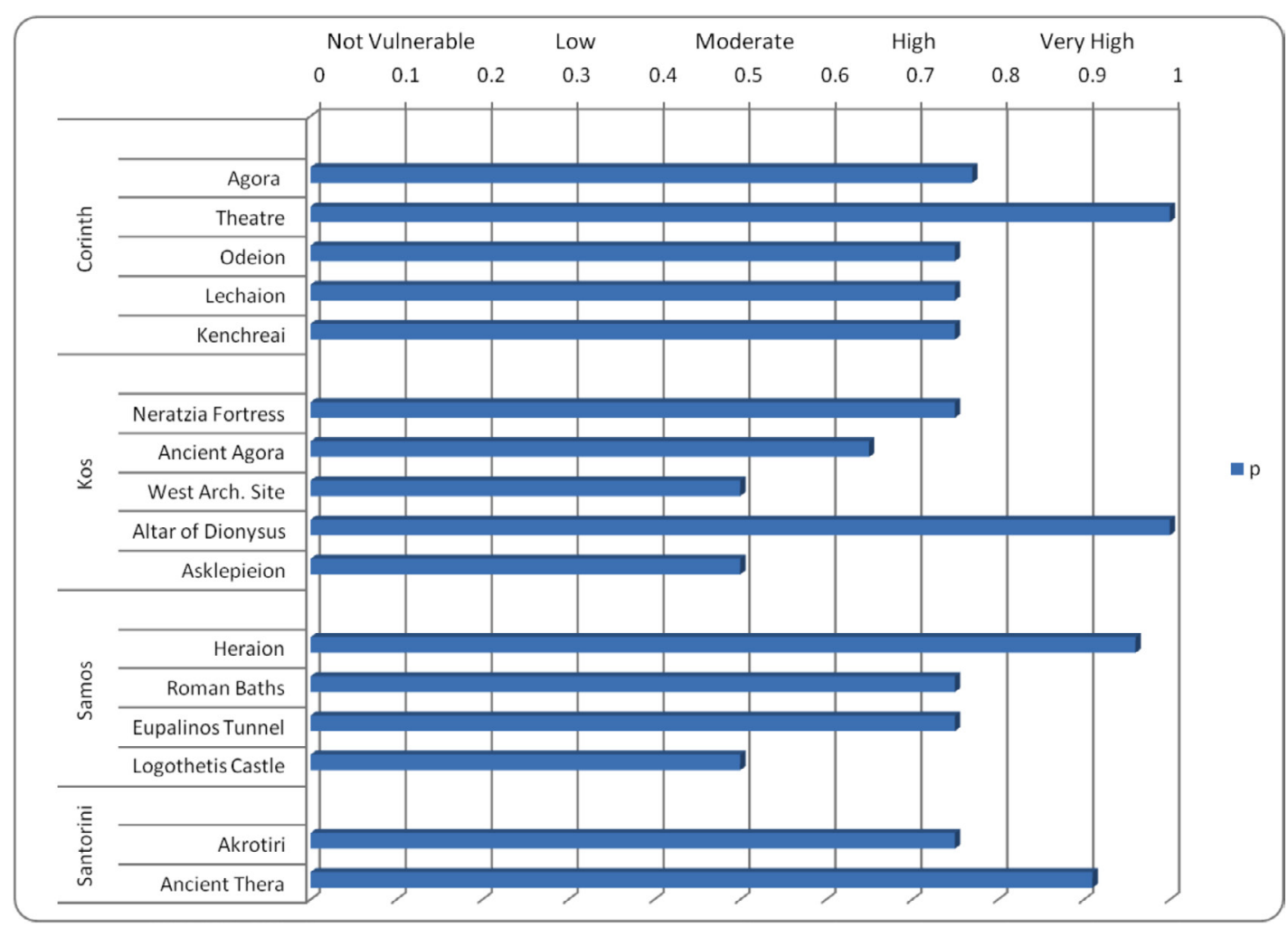

Figure 8. The physical vulnerability indicator for the archaeological sites under study.

least interventions and therefore very high physical vulnerability (Figure 8; Table 5). Their scores indicate that the majority of the sites have undergone interventions restricted mainly to conservation works. Restoration, anastylosis and reconstructions works are limited to specific monuments in the archaeological sites of Kos (Asklepieion (0.5), West Archaeological site (0.5), Ancient Agora $(0.65)$ ), in the Lykourgos Logothetis Castle (0.5) in Samos and in Agora in Corinth (0.77) that results in their classification of moderate or high physical vulnerability. No site is characterised by low or no physical vulnerability reflecting the limited extent and types of interventions on the monuments of the sites. Although such practices are in agreement with the charters of Athens 1931 and Venice 1964 for the preservation of their authenticity value, they are contributing to a limited extent to the resilience of the monuments against a future seismic event.

\subsubsection{Economic importance}

The application of the economic importance indicator suggests that seven out of sixteen archaeological sites have admission tickets and can be considered as valuable to the local and national economy and consequently contributing to their vulnerability (Table 5 in the Appendix). At a regional level, it is interesting to note that in Corinth only the Agora site is assigned with admission ticket (1 site out of 5), in contrast to Samos (2 sites out of 4$)$, Kos (2 sites out of 5) and Santorini island (2 sites out of 2 ). This observation suggests that any earthquake damage to the archaeological sites in Santorini will result in higher impacts to the national and local economy in relation to the other regions under study.

\subsubsection{Human vulnerability}

For the sites under investigation, seven have admission ticket, eight are open sites without admission and one site is closed. According to the visitors numbers based on annual records by ELSTAT [2014], the archaeological sites of Agora in Corinth, Neratzia Fortress and Asklepieion in Kos and Akrotiri in Santorini present high visitor density and therefore are considered as sites with very high human vulnerability and a score of 1 (Figure 9). Heraion and Eupalinos tunnel in Samos and Ancient Thera in Santorini have a relatively moderate visitor density reflected through the score of 0.66 , followed by the open sites of Theatre, Lechaion Harbour, Kenchreai harbour in Corinth, Ancient Agora, West archaeological site and Altar of Dionysus in Kos, Roman Baths and Lykourgos Logothetis Castle in Samos with a score of 0.33 (Table 5 in the Appendix). Finally, the Odeion in Corinth is the site with a score of 0 since it is the only site closed to the public. 


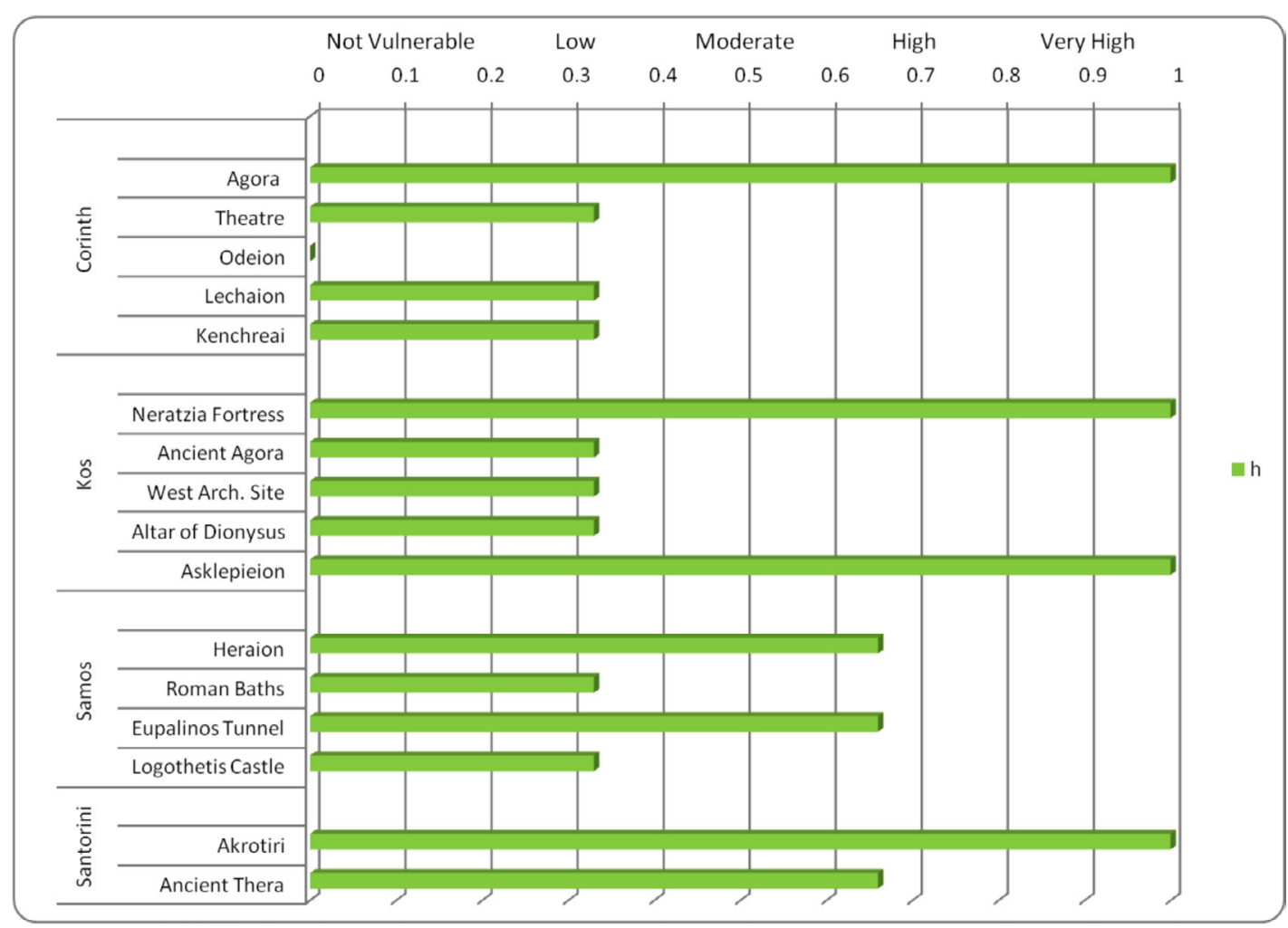

Figure 9. The human vulnerability indicator for the archaeological sites under study.

\subsubsection{Temporal Vulnerability index}

The synthesis of physical vulnerability, economic importance and human vulnerability indicators that compose the temporal vulnerability index for the archaeological sites investigated is presented in Figure 10 (Table 5 in the Appendix). The results highlight the archaeological sites of Agora in Corinth (0.923), Heraion in Samos (0.873), Neratzia Fortress in Kos (0.916) and Akrotiri in Santorini (0.916) as the sites with very high temporal vulnerability while the distribution suggests that each region has at least one site with very high temporal vulnerability. The qualitative classification of the results (Figure 10), suggests a considerable number of sites with very high temporal vulnerability while the majority of the sites are classified as having low vulnerability with only the sites of the Theatre in Corinth and the Altar of Dionysus in Kos classified as having moderate vulnerability.

The very high temporal vulnerability scores reflect sites with minor interventions, admission ticket and high visitor density suggesting that potential damage at these sites from an earthquake event is very likely and that it will be followed by major social and economical impacts both at local and national levels. On the other hand, the Asklepieion site (Kos island) represents a good example of high temporal vulnerability score that is not expected to decrease considerably with further intervention works since it is mainly attributed to the factors of admission tickets and visitors density. The clustering of the majority of the sites to low or moderate vulnerability classes is attributed to the fact that the sites are open to the public without admission tickets that are considered to attract less than 10.000 visitors per year. Their scores mainly reflect their physical vulnerability and the necessity to focus on appropriate intervention works before the sites are opened with ticketed admission.

Overall, the temporal vulnerability index might be refined in the future by considering in a more sophisticated way, variations in human density (for example) between summer and winter and day and night. Clearly sites are closed at night and may have much reduced visitor density in the winter resulting in subtle variations in overall vulnerability. If robust visitor data can be collected for key sites of interest, further refinement and testing of the method could occur.

\subsection{Archaeological Site Vulnerability Index (A.S.V.I.)}

The A.S.V.I. highlights two sites with high vulnerability - the Neratzia Fortress in Kos (0.766) and Heraion in Samos (0.741) (Table 6). Both sites have nearly the same score of SSi as indicated by the distribution of the susceptibility indicators (Figure 7). Both are equally susceptible to earthquake induced ground liquefaction and tsunami inundation due to 


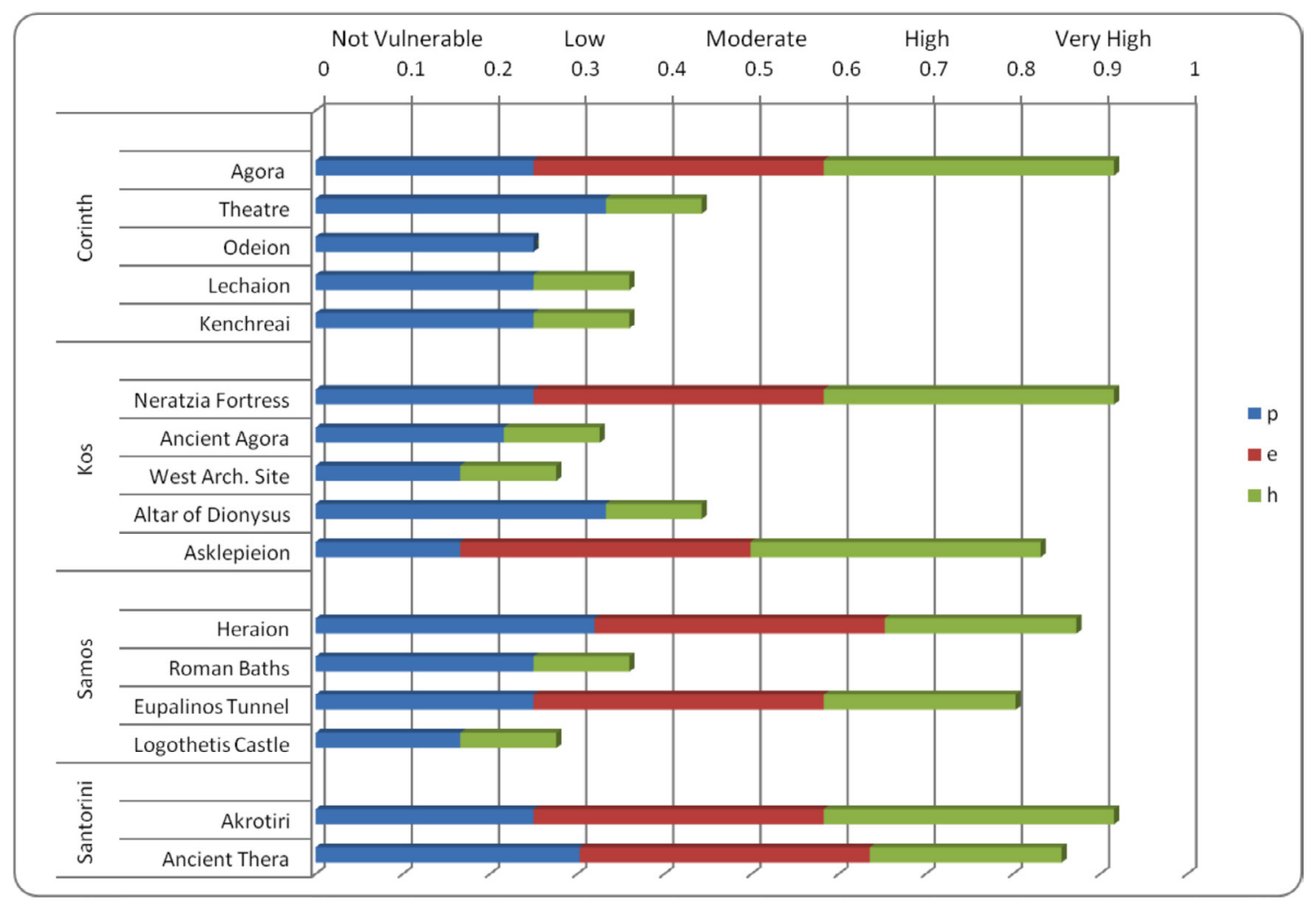

Figure 10. Temporal vulnerability index for the archaeological sites under study.

their location in the coastal zone and their depositional environments are the main common parameters. Their TVi is also very similar, with the Heraion score mainly attributed to the poor state of preservation of the site, while Neratzia Fortress attributed both to the minimum preservation works and high visitors' density. Their final A.S.V.I. score is the result of their high spatial susceptibility combined with their very high temporal vulnerability.

The majority of the sites (10 out of 16) are classified as moderately vulnerable, with Lechaion and Kenchreai scores mainly attributed to relatively high SSi, while Akrotiri, Ancient Thera, Eupalinos Tunnel, Asklepieion and Agora (Corinth) scores are mainly

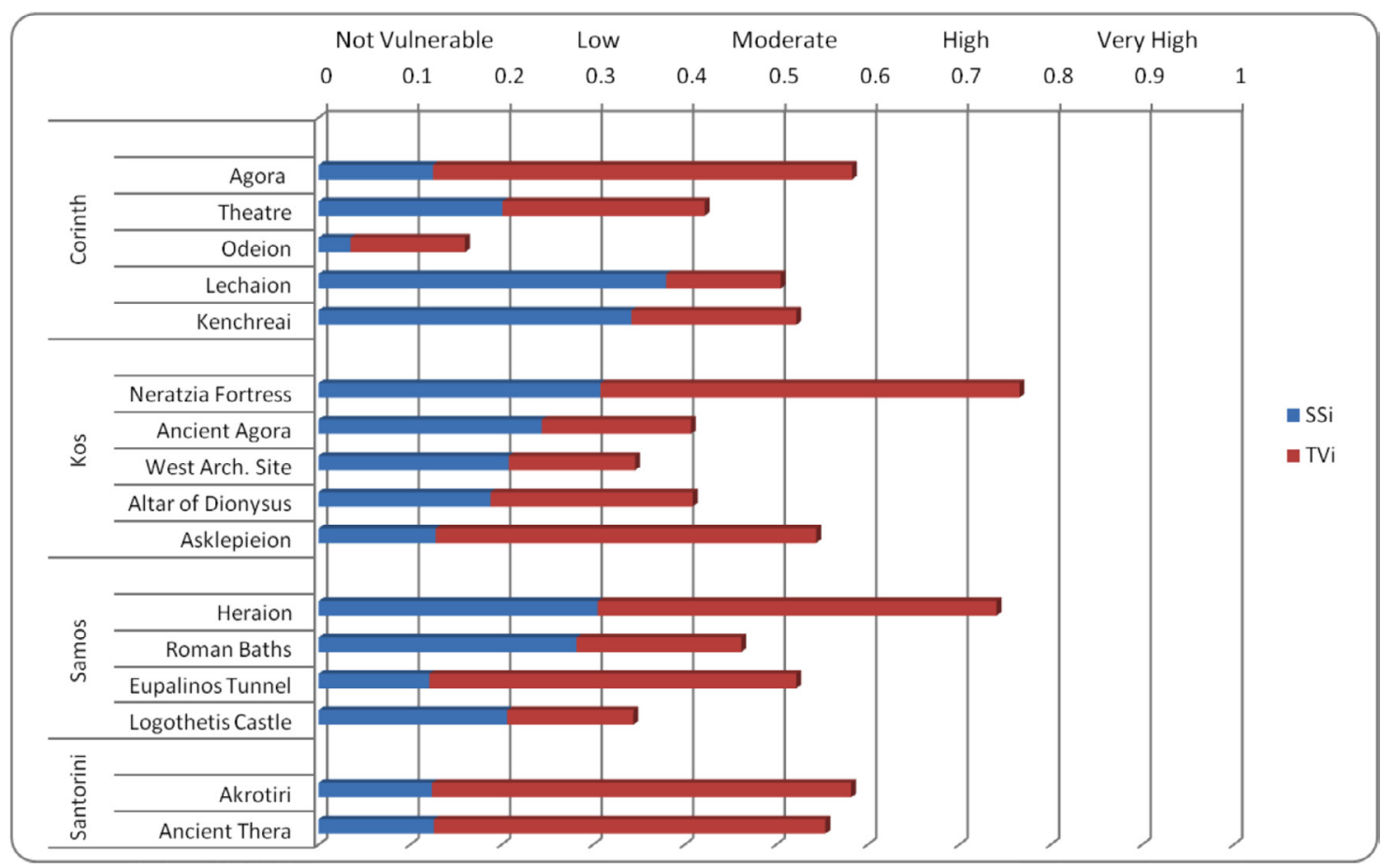

Figure 11. The A.S.V.I. index with the contribution of SSi and TVi for the archaeological sites in this study. 
attributed to high TVi. Logothetis Castle (0.344), in Samos and West Archaeological site (0.346) in Kos, are classified as low vulnerability sites. The low A.S.V.I. scores reflect low TVi for both sites (moderate state of preservation, no admission tickets and low visitors density). In contrast, the SSi indicates high susceptibility to liquefaction for the West archaeological site and high susceptibility to slope instabilities for the Logothetis Castle.

The Odeion in Ancient Corinth is the site with the lowest vulnerability index $(0.160)$. The site is characterised by the lowest $S S i$ and $T V i$ scores. It represents a site closed to the public, with limited conservation works and limited spatial susceptibility to EEEs.

It is worth mentioning that none of the sites presents very high vulnerability. This is attributed to the lack of very high SSi scores for the archaeological sites as discussed in section 3.1.4, restricting the A.S.V.I. scores through Equation 3 to values lower than 0.8, that is, not exceeding the high vulnerability class.

The distribution of A.S.V.I. scores allows an examination of the vulnerability of the archaeological sites at a regional level. In Corinth, the majority of the sites present moderate vulnerability with the Odeion classified as not vulnerable. The index scores of Agora and Theatre are mainly attributed to physical vulnerability although landslide and liquefaction susceptibility needs to be addressed and examined in detail. The Lechaion and Kenchreai harbour scores on the other hand, suggest that future studies should focus on their susceptibility to EEEs and more specifically, to ground liquefaction for the application of the appropriate mitigation measures.

In Kos and Samos, the sites range from low to high vulnerability presenting a variety in SSi and TVi contribution. For the Neratzia Fortress and Heraion in Samos multidisciplinary studies are proposed in order to examine and address their spatial susceptibility to ground liquefaction and tsunami in order to implement the appropriate interventions. Finally, the sites at Santorini are characterized by moderate vulnerability mainly attributed to temporal aspects and future studies should focus on the physical vulnerability of the sites in order to assess the necessary interventions and increase their resilience against earthquake hazard.

\section{Conclusions}

Through the integration of spatial and temporal aspects in the proposed vulnerability assessment method, we explored the relative contribution to the vulnerability of archaeological sites to earthquake hazard.
The synthesis of the Archaeological Site Vulnerability Index (A.S.V.I.) index provides the opportunity to identify the most vulnerable archaeological sites and the root causes that need to be addressed with appropriate measures and actions in order to increase their coping capacity and resilience to future earthquake hazard.

The results suggest that the archaeological sites of Neratzia Fortress in Kos and Heraion in Samos are sites with high vulnerability that need to be prioritised for further study and mitigation measures. Although the majority of the archaeological sites investigated are characterised by low to moderate vulnerability to earthquake hazard, the vast majority of the sites are susceptible to at least one secondary Earthquake Environmental Effect, promoting the spatial aspects of vulnerability as a prerequisite in disaster risk management practices for cultural heritage protection. In addition, the results indicate that relatively high physical vulnerability characterises the majority of the sites due to the existing interventions performed for their protection, that follows a general trend of limited conservation works. These interventions are in agreement with the minimal requirements of the Athens (1931) and Venice (1964) charters framework and significantly, they do not contribute to the resilience of the sites to earthquake hazard. Consequently, implementation of the charters guidelines to their full extent through restoration works is considered necessary in order to ensure optimal structural stability with minimal extent of interventions, thus preserving the aesthetic and historical value of the monuments and reducing their physical vulnerability to acceptable levels.

Summarizing, the application of the indicator based vulnerability assessment method to the selected archaeological sites in Greece, highlighted the susceptibility of the sites to secondary Earthquake Environmental Effects and focuses attention on the common practices that contribute to their physical vulnerability. The root causes of vulnerability should be integrated by the cultural heritage management institutions in to their pre-disaster planning and disaster risk management frameworks. The proposed method represents a flexible, low cost method with a promising potential for use by end-users from various disciplines at local, regional and national levels. Future research on the applicability of this method that explores its potential and its limitations represent essential steps towards the development of a holistic and effective vulnerability assessment methodology in the framework of disaster risk management for Cultural Heritage protection. In addition to the various suggestions made through 
for testing and refinement of aspects of the method, one last and potentially very useful step would be to consult with international experts in this area and seek their expert judgement on the factors we have identified and weighted. Specifically, we could invite experts to identify factors we have not considered and offer weightings or the various factors in order to gain a consensus on the method embedded in expert-led, field based experience.

Acknowledgements. We would like to express our gratitude to the Greek Ministry of Culture and Sports and the Directors of the regional Ephorates for granting us permission to carry out the study on the selected archaeological sites and for assisting us in data collection. The research was conducted as part of Despina Minos-Minopoulos PhD thesis in the Department of Geography, Harokopion University, Athens, Greece.

\section{References}

Alves, F.L., Coelho, C., Coelho, C.D. and P. Pinto (2011). Modelling Coastal Vulnerabilities - Tool for Decision Support System at Inter-municipality Level. Journal of Coastal Research, SI 64 (Proceedings of the 11th International Coastal Symposium), 966970. Szczecin, Poland, ISSN 0749-0208.

Asteris, P.G., Chronopoulos, M.P., Chrysostomou, C.Z., Varum, H., Plevris, V., Kyriakides, N. and V. Silva (2014). Seismic vulnerability assessment of historical masonry structural systems. Engineering Structures, 62-63, 118-134.

Australia ICOMOS (2013). The Burra Charter: The Australia ICOMOS Charter for places of cultural significance, 2013, Available at: http://australia. icomos.org/publications/charters/

Bana e Costa, C.A., De Corte, J. M. and J.C. Vansnick (2005). On the mathematical foundations of MACBETH. In: Figueira, J., Greco, S. and Ehrgott, M., (eds). Multiple Criteria Decision Analysis: State of the Art Surveys, Springer.

Bana e Costa, C.A., Oliveira, C.S. and V. Vieira (2008). Prioritization of bridges and tunnels in earthquake risk mitigation using multicriteria decision analysis: Application to Lisbon. Omega 36, 442-450

Bird, J.F. and J.J. Bommer (2004). Earthquake losses due to ground failure, Engineering Geology, 75, 147-179.

Calgaro, E., Lloyd, K. and D. Dominey-Howes (2014). From vulnerability to transformation: a framework for assessing the vulnerability and resilience of tourism destinations. Journal of Sustainable Tourism, 22:3, 341-360.

Canuti, P., Casagli, N., Catani, F. and R. Fanti (2000). Hydrogeological hazard and risk in archaeological sites: some case studies in Italy. Journal of Cultural Heritage, 1, 117-125.

Canuti, P., Margottini, C., Fanti, R. and E. Bromhead (2009). Cultural heritage and landslides: Research for risk prevention and conservation. In: Sassa, K., Canuti, P., (eds), Landslides - Disaster Risk Reduction, Springer-Verlag, Berlin, Heidelberg, 2009, pp. 401-433.

Carlon, C., Marcomini, A., Fozzati, L., Scanferla, P., Bertazzon, S., Bassa, S., Zanovello, F., Stefano, F., Chiarlo, R. and F. Penzo (2002). ArcheoRisk: a decision support system on the environmental risk for archeological sites in the Venice lagoon. Proceedings of the 1st Biennial Meeting of the iEMSs, Lugano, Switzerland.

Chandrasekar, N., Saravanan, S., Pajamanickam, M., Hentry, C. and G.V. Rajamanickam (2012). Correlation between coastal geomorphology and tsunami inundation along the coast of Kanyakumari, India. J. Ocean Univ. China, 11 (1), 1-6.

Choowong, M., Murakoshi, N., Hisada, K., Charusiri, P., Daorerk, V., Charoentitirat, T., Chutakositkanon, V., Jankaew K. and P. Kanjanapayont (2007). Erosion and Deposition by the 2004 Indian Ocean Tsunami in Phuket and Phang-nga Provinces, Thailand. Journal of Coastal Research, 23, 1270-1276.

CIAM (1931). The Athens Charter for the Restoration of Historic Monuments, First International Congress of Architects and Technicians of Historic Monuments., Athens 1931. Available at: http:// www.icomos.org/en/charters-and-texts / 179-articles-enfrancais / ressources/ charters-and-standards / 167-the-athens-charter-for-therestoration-ofhistoric-monuments [accessed 15.5.2015].

Dall' Osso, F., Gonella, M., Gabbianelli, G., Withycombe, G. and D. Dominey-Howes (2009). A revised (PTVA) model for assessing the vulnerability of buildings to tsunami damage. Nat. Hazards Earth Syst. Sci., 9, 1557-1565.

Dawson, A.G. (1994). Geomorphological effects of tsunami run-up and backwash. Geomorphology, 10, 83-94.

Delmonaco, G. and C. Margottini (2009). Exposure and vulnerability of cultural heritage affected by geomorphological hazard: The Machu Picchu case study. In Mazzolani (ed) Protection of Historical Buildings, Taylor $\&$ Francis Group, London, ISBN 978-0-415-55803-7, p. 905-909.

Di Capua, G., Curti, E., Lemme, A., Peppoloni, S. and S. Podesta (2006). Simplified parameters for the evaluation of site effects in the seismic risk analyses 
of monuments. Proceedings of the First European Conference on Earthquake Engineering and Seismology, Geneva, Switzerland, 3-8 September 2006, paper no. 656 .

Dominey-Howes, D.T.M. (1996). 'Sedimentary deposits associated with the July 9th 1956 Aegean Sea tsunami', Physics and Chemistry of the Earth, 21,. 1-2 Special Issue, 51 - 55.

Dominey-Howes, D. (2002). Documentary and Geological Records of Tsunamis in the Aegean Sea Region of Greece and their Potential Value to Risk Assessment and Disaster Management. Natural Hazards, 25, 195-224.

ELSTAT (2014). Admissions to archaeological sites by month, year 2013. Available at: http://www. statistics.gr/portal/page/portal/ESYE/PAGEthemes?p_param $=A 1802 \&$ r_param $=S C I 21 \& y_{-}$ param $=$ TS\& $m y t a b s=0$

Foumelis, M., Lekkas, E. and I. Parcharidis (2004). Landslide susceptibility mapping by GIS-based qualitative weighting procedure in Corinth area. Bull. Geol. Soc. Greece, XXXVI, Proceedings of the 10th International Congress, Thessaloniki, April 2004. 904-912.

Fritz, H., Borrero, J., Synolakis, C., Okal, E., Weiss, R., Titov, V., Jaffe, B., Foteinis, S., Lynett, P., Chan I. and P. Liu (2011). Insights on the 2009 South Pacific tsunami in Samoa and Tonga from field surveys and numerical simulations. Earth-Science Reviews, 107, 66-75.

Geist, E.L. (2001). Modelling the natural complexity of local tsunamis, ITS 2001 Proceedings, session 7, number 7-5, 751-758.

Goto, K., Fujima, K., Sugawara, D., Fujino, S., Imai, K., Tsudaka, R., Abe, T. and T. Haraguchi, (2011). Field measurements and numerical modelling for the run-up heights and inundation distances of the 2011 Tohoku-oki tsunami at Sendai Plain, Japan. Earth Planets Space, 64, 1247-1257.

Hadler, H., Vött, A., Koster, B., Mathes-Schmidt, M., Mattern, T., Ntageretzis, K., Reicherter, K. and T. Willershäuser (2013). Multiple late-Holocene Tsunami Landfall in the Eastern Gulf of Corinth Recorded in the Palaeotsunami Geo-archive at Lechaion, Harbour of Ancient Corinth (Peloponnese, Greece). Zeitschrift für Geomorphologie 57, 4, 139-180.

ICOMOS (1965). International Charter for the Conservation and Restoration of Monuments, (The Venice Charter, 1964). 2nd International Congress of Architects and Technicians of Historic Monuments,
Venice, 25-31 May 1964. Available at: http:/ / www. international.icomos.org/charters/venice_e.pdf

ICOMOS (2001). Recommendations for the analysis, conservation and structural restoration of architectural heritage. Document approved by the Committee in the meeting held in Paris, 13 September 2001.

Jigyasu, R. (2005). Towards developing methodology for integrated risk management of cultural heritage sites and their settings. Proceedings of the ICOMOS 15th General Assembly and scientific symposium, Xi' an, China, 17-21 October 2005, Section II, paper no. 16.

Keefer, D.K. (1984). Landslides Caused by Earthquakes, Geological Society of America Bulletin 95, 406-421.

Keefer, D.K. (2000). Statistical analysis of an earthquake-induced landslide distribution - the 1989 Loma Prieta, California event. Engineering Geology, 58, 231-249.

Keefer, D.K. (2002). Investigating landslides caused by earthquakes - A historical review. Surveys in Geophysics, 23, 473-510.

Kouli, M., Loupasakis, C., Soupios, P., Rozos, D. and F. Vallianatos (2014). Landslide susceptibility mapping by comparing the WLC and WofE multi-criteria methods in the West Crete Island, Greece. Environ Earth Sci 72, 5197-5219.

Ladas, I., Fountoulis, I. and I. Mariolakos (2007). Large scale landslide susceptibility mapping using GISbased weighted linear combination and multicriteria decision analysis - a case study in northern Messinia (SW Peloponnesus, Greece). Proceedings of the 8th Conference of the Hellenic Geographical Society, pub. no. 119.

Lagomarsino, S. (2006). On the vulnerability assessment of monumental buildings. Bull. Earthquake Eng. 4, 445-463.

Lagomarsino S. and S. Cattari (2015). PERPETUATE guidelines for seismic performance-based assessment of cultural heritage masonry structures. Bulleting of Earthquake Engineering, 13, 1, 13-47.

Lekkas, E., Minos-Minopoulos, D. and E. Stefanidou (2010). Emergency planning for the municipality of Kos, Kos Island, Greece. In: Williams et al. (eds), 2010. Geologically Active. Taylor \& Francis Group, London, ISBN 978-0-415-60034-7

Lekkas, E., Andreadakis, E., Kostaki, I. and E. Kapourani (2011). Critical factors for run-up and impact of the Tohoku earthquake. International Journal of Geosciences, 2, 310-317.

Mallouchou-Tufano. F. (2007). The restoration of clas- 
sical monuments in modern Greece: historic precedents, modern trends, peculiarities. Conservation and management of Archaeological sites, 2007, 8, 154-173.

Matsutomi, H., Shuto, N., Imamura F., and T. Takahashi (2001). Field Survey of the 1996 Irian Jaya Earthquake Tsunami in Biak Island. Natural Hazards, 24, 199-212.

Michetti, A.M., Esposito, E., Guerrieri, L., Porfido, S., Serva, L., Tatevossian, R., Vittori, E., Audemard, F., Azuma, T., Clague, J., Comerci, V., Gürpinar, A., McCaplin, J., Mohammadioun, B., Mörner, N.A., Ota, Y. and E. Roghozin (2007). Intensity scale ESI 2007. In Guerrieri L. and E. Vittori (eds). Mem. Descr. Carta Geol. D’It. LXXIV (2007), 73 pp.

Michetti, A.M., Esposito, E., Guerrieri, L., Porfido, S., Serva, L., Tatevossian, R., Vittori, E., Audemard, F., Azuma, T., Clague, J., Comerci, V., Gürpinar, A., McCaplin, J., Mohammadioun, B., Mörner, N.A., Ota, Y. and E. Roghozin (2015). Environmental Seismic Intensity scale - ESI 2007 (English). In Guerrieri, L. (eds) Earthquake Environmental Effects for seismic hazard assessment: the ESI intensity scale and the EEE catalogue, Mem. Descr. Carta Geol. D’It. XCVII (2015), pp. 11-20.

Minos-Minopoulos, D., Pavlopoulos, K., Apostolopoulos, G., Lekkas, E. and D. Dominey-Howes (2015). Liquefaction features at an archaeological site: Investigations of past earthquake events at the Early Christian Basilica, Ancient Lechaion Harbour, Corinth, Greece. Tectonopysics, 658, 74-90.

Minos-Minopoulos, D. (2015). Vulnerability and Risk of archaeological sites to geological - geomorphological processes. $\mathrm{PhD}$ thesis, Harokopio University, pp. 382. Available at: http://www.didaktorika. $\mathrm{gr} /$ eadd $/$ handle $/ 10442 / 36524$ ? locale $=$ en

Minos-Minopoulos, D., Dominey-Howes, D. and K. Pavlopoulos (2016). Spatial Susceptibility of archaeological sites to Earthquake Environmental Effects (EEEs). Bulletin of the Geological Society of Greece, vol. L, 2016, Proceedings of the 14th Intern. Conference, Thessaloniki, May 2016, (in press).

Morhange, C., Salamon, A., Bony, G., Flaux, C., Galili, E., Goiran J-P. and D. Zviely (2012). Geoarchaeology of tsunamis and the revival of neo-catastrophism in the eastern Mediterranean. Proceedings of the Reading Catastrophes International Conference, 3-4th December 2012, Rome.

Mori, N., Takahashi, T., Yasuda T., and H. Yanagisawa (2011). Survey of 2011 Tohoku earthquake tsunami inundation and runup, Geophysical Research Letters, 38, L00G14.

Musungu, K., Motala, S. and J. Smit (2012). Using Multi-criteria Evaluation and GIS for Flood Risk Analysis in Informal Settlements of Cape Town: The case of Graveyard Pond. South African Journal of Geomatics, 1, 1, 77-91.

Nikolova, M., Nedkov, S. and V. Nikolov (2012). Risk from natural hazards for the archaeological sites along Bulgarian Danube bank. Proceeding of the European SCGIS Conference "Best practices: Application of GIS technologies for conservation of natural and cultural heritage sites", 90-96.

Obermeier, S.F., Jacobson, R.B., Smoot, J.P., Weems, R.E., Gohn, G.S., Monroe, J.E., and D.S. Powars (1990). Earthquake-induced liquefaction features in the Coastal setting of South Carolina and in the Fluvial setting of the New Madrid Seismic Zone. USGS Professional paper 1504.

Obermeier, S.F. (2009). Using Liquefaction-Induced and other soft-sediment features for paleoseismic analysis. In McCaplin, J., (eds) (2009). Paleoseismology, International Geophysics, 95, DOI: 10.1016/ S0074-6142(09)95007-0.

Papadopoulos, G. and A. Fokaefs (2005). Strong tsunamis in the Mediterranean Sea: a re-evaluation. ISET Journal of Earthquake Technology, 463, 42, 4, 159-170.

Papathoma, M. and D. Dominey-Howes (2003). Tsunami vulnerability assessment and its implications for coastal hazard analysis and disaster management planning, Gulf of Corinth, Greece. Natural Hazards and Earth System Sciences, 3, 733-747.

Papathoma-Köhle, M., Neuhäuser, B., Ratzinger, K., Wenzel, H. and D. Dominey-Howes (2007). Elements at risk as a framework for assessing the vulnerability of communities to landslides. Natural Hazards and Earth System Sciences, 7, 765-779.

Reeder, L.A., Rick, T.C. and J.M. Erlandson (2012). Our disappearing past: a GIS analysis of the vulnerability of coastal archaeological resources in California's Santa Barbara Channel region. J. Coast. Conserv. 16, 187-197.

Reeder-Myers, L.A. (2015). Cultural heritage at risk in the twenty-first century: A vulnerability assessment of coastal archaeological sites in the United States. Journal of Island and Coastal Archaeology, 0, 1-10,

Rodríguez, C.E., Bommer, J.J. and R.J. Chandler (1999). Earthquake-induced Landslides: 1980-1997, Soil Dynamics and Earthquake Engineering 18, 
325-346.

Rodríguez-Pascua, M.A., Pérez-López, R., Giner-Robles, J.L., Silva, P.G., Garduňo-Monroy, V.H. and K. Reicherter (2011). A comprehensive classification of Earthquake Archaeological Effects (EAE) in archaeoseismology: Application to ancient remains of Roman and Mesoamerical cultures. Quaternary International, 242, 20-30.

Rozos, D., Bathrellos, G.D. and H.D. Skillodimou (2011). Comparison of the implementation of rock engineering system and analytic hierarchy process methods, upon landslide susceptibility mapping using GIS: a case study from the Eastern Achaia County of Peloponnesus, Greece. Environ Earth Sci 63, 49-63.

Saaty, R.W. (1987). The Analytic Hierarchy Process What it is and how it is used. Math Modelling, 9, 3-5, 161-176.

Sabatakakis, N., Koukis, G., Vassiliades, E. and S. Lainas, S (2013). Landslide susceptibility zonation in Greece. Nat. Hazards, 65, 523-543.

Samant, L.D., Tobin, L.T. and B. Tucker (2008). Preparing your community for tsunamis: A guidebook for local advocates. Geohazards International, Working Draft, Version 2.1.

Serva, L., Blumetti, A.M., Esposito, E., Guerrieri, L., Michetti, A.M., Okumura, K., Porfido, S., Reicherter, K., Silva, P.G. and E. Vittori (2015). Earthquake Environmental Effects and seismic hazard assessment: The lessons of some recent large earthquakes. Mem. Descr. Carta Geol. D’It. XCVII (2015), pp. 5-8..

Tanaka, H., Tinh, N.X., Umeda, M., Hirao, R., Pradjoko, E., Mano, A. and K. Udo (2012). Coastal and estuarine morphology changes induced by the 2011 Great East Japan earthquake tsunami. Coastal Engineering Journal, 54, 1, 1250010.

Tarbotton, C., Dominey-Howes, D., Goff, J.R., Papathoma-Kohle, M., Dall'Osso, F and I.L. Turner (2012). GIS-based techniques for assessing the vulnerability of buildings to tsunami: current approaches and future steps. Geological Society, London, Special Publications 2012, 361, 115-125.

UNESCO (2010). Managing Disaster Risks for World Heritage, World Heritage Resource Manual, UNESCO. Available at: http://whc.unesco.org/en/ activities / 630/ [accessed 14.12. 2011].

Varnes, D.J. (1984). Landslide hazard zonation: a review of principles and practice. Commission on landslides on the IAEG, UNESCO, Natural Hazards no.3, 61pp.
Youd, T.L. and S.N. Hoose (1977). Liquefaction susceptibility and geologic setting. World Conference on Earthquake Engineering, 6th, New Delhi 1977, Proceedings, 3, 2189-2194.

Youd, T.L. and D.M. Perkins (1978). Mapping liquefaction-induced ground failure potential. Proceedings of the American Society of Civil Engineers, Journal of the Geotechnical Engineering Division, 104, GT4, 433-446.

Youd, T. L. (1984). Recurrence of liquefaction at the same site. Proceedings of the Eighth World Conference on Earthquake Engineering, Earthquake Engineering Research Institute, San Francisco, Calif., 3, 231-238.

Youd, T. L. (1998). Screening Guide for Rapid Assessment of Liquefaction Hazard at Highway Bridge Sites. Technical Report MCEER-98-0005, Multidisciplinary Centre for Earthquake Engineering Research, State University of New York, Buffalo. 76p.

${ }^{*}$ Corresponding author: Dale Dominey-Howes

The University of Sydney, School of Geosciences, Sydney NSW 2050, Australia;

email: dale.dominey-howes@sydney.edu.au

2017 by Istituto Nazionale di Geofisica e Vulcanologia.

All rights reserved 